\title{
Selective Deletion of Cochlear Hair Cells Causes Rapid Age-Dependent Changes in Spiral Ganglion and Cochlear Nucleus Neurons
}

\author{
Ling Tong, ${ }^{1,2 *}$ Melissa K. Strong, ${ }^{1,2 *}$ Tejbeer Kaur, ${ }^{6}$ Jose M. Juiz, ${ }^{5}$ Elizabeth C. Oesterle, ${ }^{1,2}$ Clifford Hume, ${ }^{1,2}$ \\ Mark E. Warchol, ${ }^{6}{ }^{\circ}$ Richard D. Palmiter, ${ }^{3}$ and ${ }^{-E d w i n ~ W ~ R u b e l ~}{ }^{1,2,4}$ \\ ${ }^{1}$ Virginia Merrill Bloedel Hearing Research Center, ${ }^{2}$ Department of Otolaryngology-Head and Neck Surgery, ${ }^{3}$ Department of Biochemistry and Howard \\ Hughes Medical Institute, and ${ }^{4}$ Department of Physiology and Biophysics, University of Washington, Seattle, Washington 98195, ${ }^{5}$ Discapacidades \\ Neurológicas and School of medicine, Universidad de Castilla-La Mancha, 02008 Albacete, Spain, and ${ }^{6}$ Department of Otolaryngology, Washington \\ University School of Medicine, St. Louis, Missouri 63110
}

During nervous system development, critical periods are usually defined as early periods during which manipulations dramatically change neuronal structure or function, whereas the same manipulations in mature animals have little or no effect on the same property. Neurons in the ventral cochlear nucleus $(\mathrm{CN})$ are dependent on excitatory afferent input for survival during a critical period of development. Cochlear removal in young mammals and birds results in rapid death of target neurons in the CN. Cochlear removal in older animals results in little or no neuron death. However, the extent to which hair-cell-specific afferent activity prevents neuronal death in the neonatal brain is unknown. We further explore this phenomenon using a new mouse model that allows temporal control of cochlear hair cell deletion. Hair cells express the human diphtheria toxin (DT) receptor behind the Pou $4 f 3$ promoter. Injections of DT resulted in nearly complete loss of organ of Corti hair cells within 1 week of injection regardless of the age of injection. Injection of DT did not influence surrounding supporting cells directly in the sensory epithelium or spiral ganglion neurons (SGNs). Loss of hair cells in neonates resulted in rapid and profound neuronal loss in the ventral $\mathrm{CN}$, but not when hair cells were eliminated at a more mature age. In addition, normal survival of SGNs was dependent on hair cell integrity early in development and less so in mature animals. This defines a previously undocumented critical period for SGN survival.

Key words: cochlea; cochlear nucleus; critical period; diphtheria toxin receptor knock-in; neuronal death; spiral ganglion

\section{Introduction}

Normal development of sensory systems and sensory processing is dependent on an organism's interaction with its environment and intact sensory receptor activity (Hebb, 1949; Grubb and Thompson, 2004). Beginning with the classic contribution of Levi-Montalcini (1949), studies have shown that sensory input from the ear is necessary for the complete survival of developing neurons in the cochlear nucleus $(\mathrm{CN})$ of mammals and its avian

\footnotetext{
Received May 29, 2014; revised March 23, 2015; accepted April 7, 2015.
}

Author contributions: L.T., M.K.S., T.K., J.M.J., E.C.O., C.H., M.E.W., R.D.P., and E.W.R. designed research; L.T. M.K.S., T.K., J.M.J., E.C.O., C.H., and R.D.P. performed research; R.D.P. contributed unpublished reagents/analytic tools; L.T., M.K.S., T.K., J.M.J., E.C.O., M.E.W., and E.W.R. analyzed data; M.K.S., T.K., R.D.P., and E.W.R. wrote the paper.

This work was supported by the National Institutes of Health (Grants DC03829, DC04661, DC005361, DC006283, and DC04665), the Hearing Health Foundation, and the Hamilton and Mildred Kellogg Trust. J.M.J. was the recipient of a sabbatical scholarship grant from the Government of Spain (Programa Salvador de Madariaga MEC PR20110427). We thank Robin Gibson, Linda Robinson, Dale Cunningham, and Irina Omelchenko for technical assistance; Allen Ryan for providing the transgenic Pou4f3-GFP reporter mice; and Jennifer Larson for comments on the manuscript.

The authors declare no competing financial interests.

*L.T. and M.K.S. contributed equally to this work.

Correspondence should be addressed to Edwin W. Rubel, Virginia Merrill Bloedel Hearing Research Center, University of Washington, Box 357923, Seattle, WA 98195-7923. E-mail: rubel@uw.edu.

DOI:10.1523/JNEUROSCI.2179-14.2015

Copyright $\odot 2015$ the authors $\quad 0270-6474 / 15 / 357878-14 \$ 15.00 / 0$ counterparts, the nucleus magnocellularis and nucleus angularis. That is, removal of the anlage of the inner ear early in development or destruction of the cochlea early in postnatal development causes massive cell death in the postsynaptic neurons in the brainstem (Trune, 1982, 1983; Born and Rubel, 1985; Hashisaki and Rubel, 1989; Tierney et al., 1997; Mostafapour et al., 2000; Harris and Rubel, 2006). However, the equivalent manipulation after this critical period results in little or no transneuronal neuron loss and less pathology in the surviving neurons. Similar phenomena are well documented in the visual system (Guillery, 1973; Kalil, 1980; Galli-Resta et al., 1993), olfactory system (Frazier-Cierpial and Brunjes, 1989), and somatosensory system (Baldi et al., 2000).

The cellular events underlying these interactions have been studied extensively in brainstem auditory regions of birds and mammals (Rubel and Fritzsch, 2002; Parks and Rubel, 2004; Harris and Rubel, 2006; Sanes and Woolley, 2011), particularly in the spherical cell region of the ventral $\mathrm{CN}$. These neurons are rather uniform in size and shape, easy to count, and receive the overwhelming majority of their excitatory input via the large, eighthnerve synaptic ending, the end bulb of Held (Ryugo and Parks, 2003; Lauer et al., 2013). This critical period corresponds to the period before the development of behavioral and electrophysio- 
logical responses to sound. Destroying the cochlea in more mature mammals has little or no effect on neuronal survival. The primary method used in the studies mentioned above has been to remove the entire sensory organ surgically, thereby damaging or destroying all tissues in the inner ear, including the spiral ganglion neurons (SGNs). Therefore, it is impossible to determine whether the source of trophic support in the young $\mathrm{CN}$ is hair cells and the resulting changes in synaptic activity or other elements in the cochlea. Development of methods to prevent transneuronal degenerative CNS changes after peripheral hearing loss requires a model in which the hair cells are selectively removed at any age.

Here, we characterize a mouse model that allows temporal control of hair cell deletion by activation of the human diphtheria toxin (DT) receptor (hDTR) (Palmiter, 2001; Saito et al., 2001). The hDTR is targeted to the Pou4f3 locus, which encodes a haircell-specific transcription factor. A single systemic injection of DT into neonatal or mature Pou $43^{+/ D T R}$ mice (heterozygous for the DTR gene; referred to below as "DTR mice") reliably causes complete loss of cochlear hair cells. Using this model, we show that, in contrast to adults, neuronal survival in the neonatal $\mathrm{CN}$ is dependent on survival of the hair cells and we elucidate a new critical period governing spiral ganglion cell survival.

\section{Materials and Methods}

DTR mice. Pou4f3 (Brn3.1, Brn3c) is a class IV POU domain transcription factor that has a central function in the survival of all hair cells in inner ear sensory epithelia (Erkman et al., 1996; Xiang et al., 1997). Within the inner ear, only developing and mature hair cells express Pou4f3; it is excluded from other cell types such as supporting cells and SGNs (see Fig. 1A). Only one wild-type (WT) copy of Pou4f3 is needed for normal development and hair cell function in mice (Erkman et al., 1996).

The human heparin-binding epidermal growth factor-like growth factor (HB-EGF) acts as the DTR (Mitamura et al., 1995). The mouse equivalent of this protein has several amino acid changes that make it resistant to DT. Therefore, by expressing the human DTR gene in specific cells, one can selectively ablate those cells without affecting other mouse cells (Palmiter, 2001; Saito et al., 2001). To genetically engineer $h D T R$ behind Pou4f3, a BsiW1 site was inserted into the first Pou4f3 exon just upstream of the initiation codon. A SpeI-SnaB1 fragment $(5.9 \mathrm{~kb})$ was cloned into a targeting vector as the $5^{\prime}$ arm upstream of a floxed $S v N e o$ gene, and a SnaB1-XbaI fragment $(4.4 \mathrm{~kb})$ was cloned downstream of the floxed SvNeo gene as the $3^{\prime}$ arm. The targeting construct also had flanking $P g k-D T_{A}$ and $H S V-T K$ genes for negative selection. The full coding region for $h D T R$ was cloned into the BsiWI site so that it represented the first open reading frame. A floxed $S V N e o$ gene was removed by breeding with Mox2-Cre mice and the Mox2-Cre gene was removed from the background by selective breeding. A representation of this construct is shown in Figure $1 B$. Introduction of the human DTR gene behind the Pou $4 f 3$ promoter sensitizes sensory hair cells to DT. Exogenous delivery of DT should result in specific ablation of hair cells in the inner ear and, depending on dosage, other cells expressing Pou4f3 in the body. Vestibular hair cells are also ablated in this model (Golub et al., 2012).

Two different lines of DTR mice were generated using different background strains. Originally, C57BL/6J mice were used. A second line was then created by backcrossing these mice into the $\mathrm{CBA} / \mathrm{J}$ strain. All data presented are derived from $\mathrm{CBA} / \mathrm{J}$ mice unless otherwise indicated, but similar results were obtained in all measures from both strains. Both males and females were used. Controls were age- and strain-matched WT littermates (Pou $43^{+/+}$mice) injected with DT and DTR mice injected with physiological saline. DTR mice are phenotypically normal in terms of hearing, balance, general health, and other obvious characteristics until being injected with DT. To distinguish between DTR mice and WT littermates, a tail biopsy was collected and DNA extracted using a DNA blood and tissue kit (Qiagen). The target allele was amplified using PCR
(Dream Taq Green Master Mix; Fermentas) and the following primers $(0.4 \mu \mathrm{M})$ : Pou $4 f 3$ (WT) forward 5' CAC TTG GAG CGC GGA GAG CTA G; Pou4f3-DTR (mutant) reverse 5' CCG ACG GCA GCA GCT TCA TGG TC. The PCRs were run using the following conditions: $95^{\circ} \mathrm{C}$ for 4 min, 25 cycles $\left(95^{\circ} \mathrm{C}\right.$ for $30 \mathrm{~s}, 59^{\circ} \mathrm{C}$ for $30 \mathrm{~s}, 72^{\circ} \mathrm{C}$ for $\left.1 \mathrm{~min}\right)$ and $72^{\circ} \mathrm{C}$ for $7 \mathrm{~min}$. PCR products were separated in a $1 \%$ agarose gel containing 0.25 $\mu \mathrm{g} / \mathrm{ml}$ ethidium bromide (expected band $\sim 150 \mathrm{bp}$ ).

Mice were housed with open access to food and water and were weaned from their mothers at 3 weeks of age. All procedures were approved by the Institutional Animal Care and Use Committee at the University of Washington (Seattle, WA) and adhered to the standards of the American Veterinary Medical Association and the National Institutes of Health.

Pou $4 \mathrm{f} 3$ expression. Pou $4 \mathrm{f} 3$ expression was verified in several ways: examining tissue from Pou4f3-GFP reporter mice, and by labeling tissue with an antibody against Pou4f3. Tissue from Pou4f3-GFP reporter mice at neonatal stages and at mature ages (Erkman et al., 1996; Masuda et al., 2011) was kindly shared with us by Dr. Allen Ryan (University California-San Diego) to investigate GFP expression throughout the inner ear and the brain. Expression in mouse brain was also studied with the Allen Brain Atlas and examined by quantitative RT-PCR with RNA isolated from freshly dissected tissue from parts of the brain (forebrain, midbrain, cerebellum, and hindbrain), as well as cochlea and liver in neonatal and adult mice.

To examine Pou4f3 expression in the cochlea, temporal bones were collected from mature WT littermates. Mice were terminally anesthetized with isoflurane and transcardially perfused with $4 \%$ paraformaldehyde in PBS. Temporal bones were dissected. After opening the bulla, the stapes was removed and a small opening was made in the apical turn of the cochlea. The same fixative was gently perfused through the turns of the cochlea via both the round and oval windows. Temporal bones were then immersed in the same fixative for $2 \mathrm{~h}$ at room temperature. After fixation, they were washed three times (10 min each) in PBS, pH 7.4, at room temperature. If tissue was not dissected out of the temporal bone the same day, it was kept at $4^{\circ} \mathrm{C}$ in PBS. The tissue was prepared as a whole-mount preparation. The cochlear segments of the organ of Corti were carefully dissected free from the bony labyrinth. The stria vascularis was removed or trimmed and the tectorial membrane was removed with a \#55 forceps. Whole mounts of sensory epithelium were used to examine Pou4f3 expression.

The mouse anti-Brn3c antibody (catalog \#sc81980; Santa Cruz Biotechnology, 1:200) was used to examine Pou4f3 expression. A rabbit anti-myosin VI antibody (catalog \#25-6791; Proteus Bioscience, 1:500) was used to label the hair cells selectively. Tissue was permeabilized for $4 \mathrm{~h}$ with $0.1 \%$ saponin/0.1\% Tween 20 in PBS. To prevent nonspecific binding of the primary antibody, tissue was incubated for $1 \mathrm{~h}$ in a blocking solution consisting of $5 \%$ normal serum $/ 0.1 \%$ Triton X-100 in PBS. Primary antibody incubations were performed for $1 \mathrm{~d}$ at $4^{\circ} \mathrm{C}$ in PBS, $5 \%$ donkey serum, and $0.1 \%$ Triton X-100. Fluorescent-labeled secondary antibodies were used (Alexa Fluor-488, Alexa Fluor-568; Life Technologies) at a dilution of 1:400 in the same buffer for $2 \mathrm{~h}$ at room temperature. Sections were washed after each incubation with antibody (three times for 10-15 min each) in PBS. After counterstaining nuclei with DAPI (catalog \#D9542; Sigma-Aldrich, $1 \mu \mathrm{g} / \mathrm{ml}$ ), the specimens were mounted in Vectashield (Vector Laboratories), coverslipped, and examined with confocal fluorescence microscopy.

Cultures of cochlea. Cochlear explants were prepared from both ears of 2- to 3-d-old mouse pups (Pou $\left.43^{+/ D T R} \times \mathrm{WT}\right)$ and treated in vitro with or without DT for $3 \mathrm{~d}(25 \mathrm{ng} / \mathrm{ml})$. The corresponding tail DNA of each pup was isolated for PCR genotyping. Temporal bones were isolated and placed in cold L15 medium. The bone overlaying the cochlea was carefully dissected away under a dissection microscope. The cartilaginous capsule, stria vascularis, and Reissner's membrane were then carefully removed, leaving the organ of Corti attached to the spiral ganglion. A total of 60 cultures (30 mice) from two litters were prepared. For each ear, the apical, middle, and basal turns were cultured together, apical surface up, on laminin-coated 8-well tissue culture slides (LabTek) in OptiMEM (Life Technologies) supplemented with $5 \%$ fetal calf serum. After $24 \mathrm{~h}$ in culture, $1 / 2$ of the medium was removed and replaced for 1 
ear with media supplemented with DT at a final concentration of 25 $\mathrm{ng} / \mathrm{ml}$; for the opposite ear, the medium did not contain DT. Explants were cultured for an additional $3 \mathrm{~d}$ before fixation with $4 \%$ paraformaldehyde for $2 \mathrm{~h}$ at $4^{\circ} \mathrm{C}$. To get robust and complete hair cell labeling, two antibodies were used to label the hair cells: a mouse monoclonal antiparvalbumin antibody (catalog \#MAB 1572; Millipore, 1:1000) and a rabbit anti-myosin VIIa (catalog \#25-6790; Proteus Bioscience, 1:500). To label supporting cells, a goat anti-Sox 2 antibody (catalog \#SC-17320; Santa Cruz Biotechnology, 1:500) was used. The tissue was permeabilized for 30 min with $0.1 \%$ saponin/ $0.1 \%$ Tween 20 in PBS, incubated for $1 \mathrm{~h}$ in a blocking solution consisting of $5 \%$ normal serum $/ 0.1 \%$ Triton X-100 in PBS, and in primary antibodies for $1 \mathrm{~d}$ at $4^{\circ} \mathrm{C}$ in PBS, $5 \%$ serum, and $0.1 \%$ Triton X-100. Fluorescent-labeled secondary antibodies were used (Alexa Fluor-488, Alexa Fluor-568; Invitrogen) at a dilution of $1: 400$ in the same buffer for $2 \mathrm{~h}$ at room temperature. For mouse antibodies against parvalbumin, the Mouse-on-Mouse kit (catalog \#BMK2202; Vector Laboratories) was used as specified by the manufacturer. Explants were washed after each antibody incubation (3 times for $10-15$ min each) in $0.1 \%$ Tween 20 in PBS. After counterstaining nuclei with DAPI (catalog \#D9542; Sigma-Aldrich, $1 \mu \mathrm{g} / \mathrm{ml}$ ), the specimens were mounted in Vectashield (Vector Laboratories), coverslipped, and examined with confocal fluorescence microscopy.

PCR genotyping, as described above, was performed with tail DNA corresponding to matched cochlear cultures. Post hoc analysis revealed the expected 1:1 ratio of offspring from the cross $\left(\right.$ Pou $\left.43^{+/ D T R} \times \mathrm{WT}\right)$ carrying the $h D T R$ transgene and only Pou $4 f 3^{+/ D T R}$ cultures treated with DT showed extensive hair cell loss (15 of 60 cultures). WT cultures did not show any DT-related toxicity (15 of 15).

Administration of DT. Mice received injection of DT as neonates or when mature. All DT injections in both neonatal and mature mice were made in the thigh muscle of the hind leg. Injection of DT at most of the dosages used here $(4-5 \mathrm{ng} / \mathrm{g}$ body weight in neonates and 25 $\mathrm{ng} / \mathrm{g}$ body weight in mature mice) induced a phenotype of instability and shakiness in the DTR mice that was detectable after only 2-4 d and persisted for months. There was a $<5 \%$ mortality rate after DT injection at the doses described below.

Most of the neonatal mice in this study received injection of DT at postnatal day 2 (P2). However, after discovering that hair cell loss occurs well before the age of hearing onset in mice, subsequent neonatal experiments were performed using P5 mice. This was done for the benefit of increased survival and minimizing weight loss due to injection of DT. P2 mice received a single injection of DT at $4 \mathrm{ng} / \mathrm{g}$ body weight; P5 mice received a single injection of $5 \mathrm{ng} / \mathrm{g}$.

Mature mice varied in age from P21 to P42 at the time of injection depending on the purpose of each specific experiment. For examining variations in the amount, pattern, or timing of hair cell loss, ages varied from 30 to $42 \mathrm{~d}$ at the time of injection and injection doses were 5, 15, or $25 \mathrm{ng} / \mathrm{g}$. Studies of neuronal changes in CN used P21 mice to be consistent with previous studies (Mostafapour et al., 2000; Harris and Rubel, 2006) and the DT dose was $25 \mathrm{ng} / \mathrm{g}$. Mature DTR mice (defined as $\geq \mathrm{P} 21$ for this study) given the $25 \mathrm{ng} / \mathrm{g}$ dose of DT were delayed in gaining weight compared with their littermate siblings, but weight recovered to normal levels by $\sim 14 \mathrm{~d}$ after DT treatment. WT littermates who also received DT did not show reduced weight gain. Organ of Corti tissue from both neonatally and mature-injected mice was examined at 2, 4, $6-8,10,14,21$, and $70+\mathrm{d}$ postinjection (dpi). SGN and $\mathrm{CN}$ tissues were examined at a subset of these survival times.

Cochlear hair cell counts. The time course of hair cell loss in neonates was assessed at 2, 4, 6, 10, 14, and 21 dpi in both DTR and WT mice. All animals in the group used for quantitative analyses were injected with DT ( $4 \mathrm{ng} / \mathrm{g}$ body weight, i.m.) at P2. Cochleas were collected and dissected as described above. Whole mounts of sensory epithelium were labeled with antibodies against hair cells, supporting cells, and neurofilament with a protocol similar to that used above for cultured cochleas. After the Sox2 labeling, neuronal axons and hair cells were labeled with a chicken antineurofilament (catalog \#AB-5539; Millipore, 1:5000), the mouse monoclonal anti-parvalbumin antibody, and the rabbit anti-myosin
Table 1. Timeline of experiments and analysis

\begin{tabular}{|c|c|}
\hline \multicolumn{2}{|l|}{ Pou4f3 expression } \\
\hline Tissue collected & $\mathrm{P} 2, \mathrm{P} 5, \mathrm{P} 22$, and $\mathrm{P} 75$ \\
\hline Analysis & Cochlea and brainstem tissue labeled for Pou4f3 \\
\hline \multicolumn{2}{|l|}{ Hair cell survival in vitro } \\
\hline Age harvested & P2-P3 \\
\hline $\begin{array}{l}\text { Time in culture before } \\
\text { treatment }\end{array}$ & $24 \mathrm{~h}$ \\
\hline $\begin{array}{l}\text { Days of treatment before } \\
\text { fixing }\end{array}$ & 3 \\
\hline Analysis & Cultured cochlea labeled and imaged \\
\hline \multicolumn{2}{|c|}{ Neonatal in vivo (cochlear, $\mathrm{SGN}$, and CN changes) } \\
\hline Age at time of DT injection & $\mathrm{P} 2(4 \mathrm{ng} / \mathrm{g})$ or P5 $(5 \mathrm{ng} / \mathrm{g})$ \\
\hline Tissue collected & $2,4,6-8,10,14,21$, and $70+$ dpi \\
\hline Analysis & $\begin{array}{l}\text { Cochlea labeled and hair cells counted, Rosenthal's } \\
\text { canal labeled and SGNs counted, cochlear } \\
\text { nucleus labeled and neurons counted }\end{array}$ \\
\hline \multicolumn{2}{|l|}{ Mature in vivo (ABR testing) } \\
\hline Age at time of DT injection & P28 -P35 (25 ng/g) \\
\hline Mice tested & Immediately before and $1,3,5,8$, and $21 \mathrm{dpi}$ \\
\hline Tissue collected & Immediately after ABR testing at each time point \\
\hline Analysis & $\begin{array}{l}\text { ABR threshold identified, cochlea labeled, and hair } \\
\text { cells counted }\end{array}$ \\
\hline \multicolumn{2}{|l|}{ Mature in vivo (dose response) } \\
\hline Age at time of DT injection & P30-P42 $(5,15$, or $25 \mathrm{ng} / \mathrm{g})$ \\
\hline Tissue collected & 8 and $21 \mathrm{dpi}$ \\
\hline Analysis & Cochlea labeled and hair cells counted \\
\hline \multicolumn{2}{|c|}{ Mature in vivo (cochlear, $\mathrm{SGN}$, and $\mathrm{CN}$ changes) } \\
\hline Age at time of DT injection & P21-P42 (25 ng/g) \\
\hline Tissue collected & $2,4,6-8,10,14,21$, and $70+$ dpi \\
\hline Analysis & $\begin{array}{l}\text { Cochlea labeled and hair cells counted, Rosenthal's } \\
\text { canal labeled and SGNs counted, cochlear } \\
\text { nucleus labeled and neurons counted }\end{array}$ \\
\hline
\end{tabular}

VIIa antibody described above with PBS washes in between. Primary antibody incubations were performed for $1 \mathrm{~d}$ at $4^{\circ} \mathrm{C}$ in PBS, $5 \%$ serum, and $0.1 \%$ Triton X-100. Fluorescent-labeled secondary antibodies were used (Alexa Fluor-488, Alexa Fluor-568, Alexa 647; Invitrogen) at a dilution of $1: 400$ in the same buffer for $2 \mathrm{~h}$ at room temperature. For mouse antibodies against parvalbumin, the Mouse-on-Mouse kit (catalog \#BMK2202; Vector Laboratories) was used as specified by the manufacturer. Tissues were washed, counterstained with DAPI, coverslipped, and imaged as described below. A minimum of three cochleas were processed for each treatment protocol for every experimental group.

An IX-81 inverted microscope (Olympus) integrated into an FV-1000 laser scanning confocal microscope (Olympus) was used to view the whole-mount preparations. Images were collected with a $10 \times / 0.40 \mathrm{nu}-$ merical aperture (NA) Olympus Universal Plan objective and a $40 \times / 1.3$ NA Olympus Universal Plan oil-immersion objective. Sequential image acquisition was performed to avoid bleedthrough using Fluoview software, version 1.3a. Images were imported into ImageJ version $1.42 \mathrm{a}$ software to create maximum intensity projections from $z$-series stacks, which were saved as 24-bit RGB TIFFs. The figures created with Adobe Photoshop CS version 8 were subjected to histogram stretch and adjustment to fill the dynamic range and to compensate for printing. For quantification of hair cell density, the number of hair cells was counted along a 200-350 $\mu \mathrm{m}$ length of sensory epithelium from each of five different regions along the sensory epithelium. These five regions were evenly spaced across the length of the sensory epithelium (apex tip to basal hook) and converted to a linear density. Hair cells were counted in both WT and DTR mice. The counts in the WT and DTR-injected littermates were averaged for each region. A minimum of three cochleas were counted and averaged for all data presented.

The procedures for quantification of hair cell loss after DT injection were similar in mature animals (P25-P28) with the following exceptions. Survival times after DT injections were $2-3 \mathrm{~d}, 4 \mathrm{~d}$, and $6 \mathrm{~d}$. Tissue was processed for detection of hair cells (myosin VIIA and parvalbumin), nerve processes (neurofilament), and cellular nuclei (DAPI). Samples 


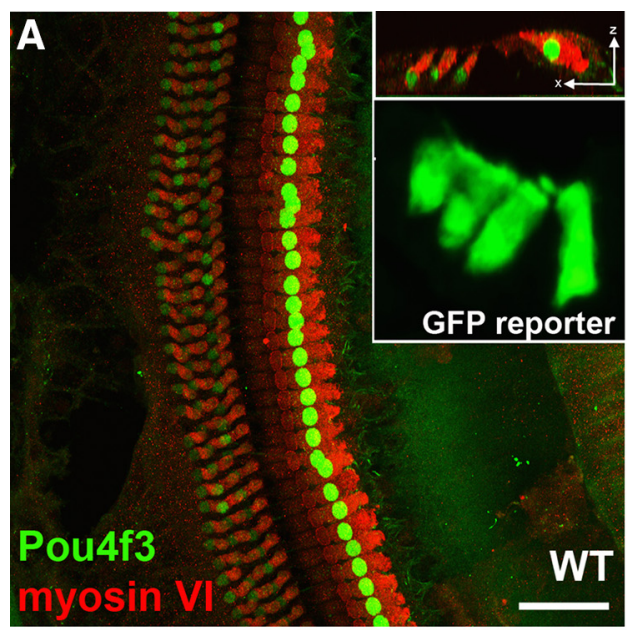

$B$

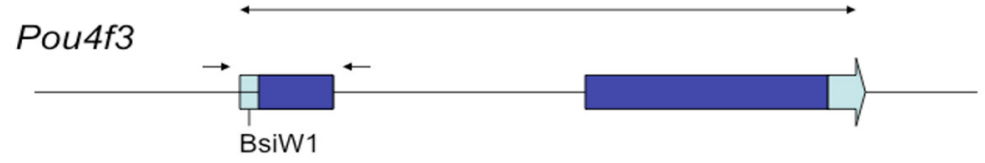

Pou4f3

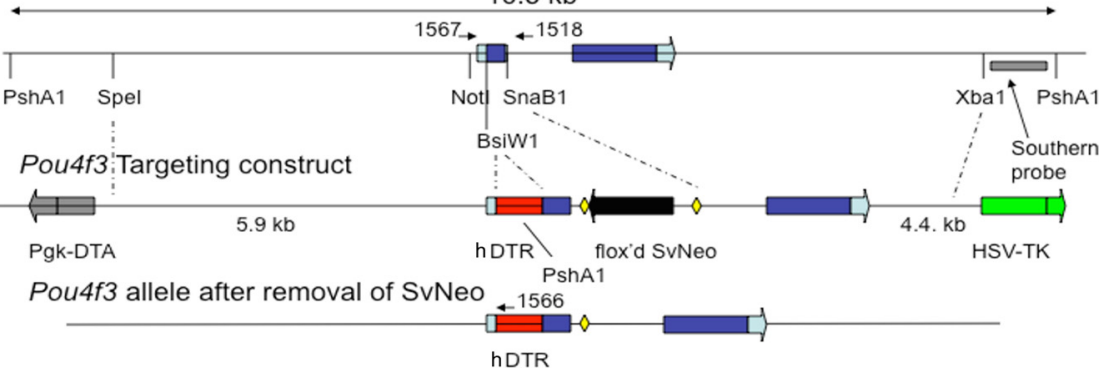

Figure 1. Pou4f3 expression is limited to hair cells. Expression of Pou4f3 was verified two ways: by labeling sectioned tissue with the Pou4f3 antibody and also using sectioned tissue from the Pou4f3-GFP reporter mouse. A, Pou4f3 (green) is selectively expressed in the nuclei of hair cells (red) from a mature (P56) WT mouse. An orthogonal view from the same section is shown in the top

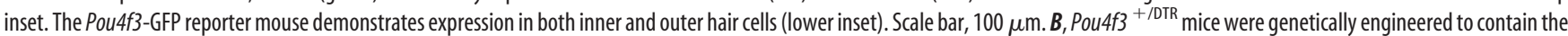
DT receptor downstream of the Pou4f3 promoter. Insertion of the DT receptor downstream of the Pou4f3 promoter creates a mouse model in which sensory hair cells in the inner ear can be selectively ablated after a systemic injection of DT.
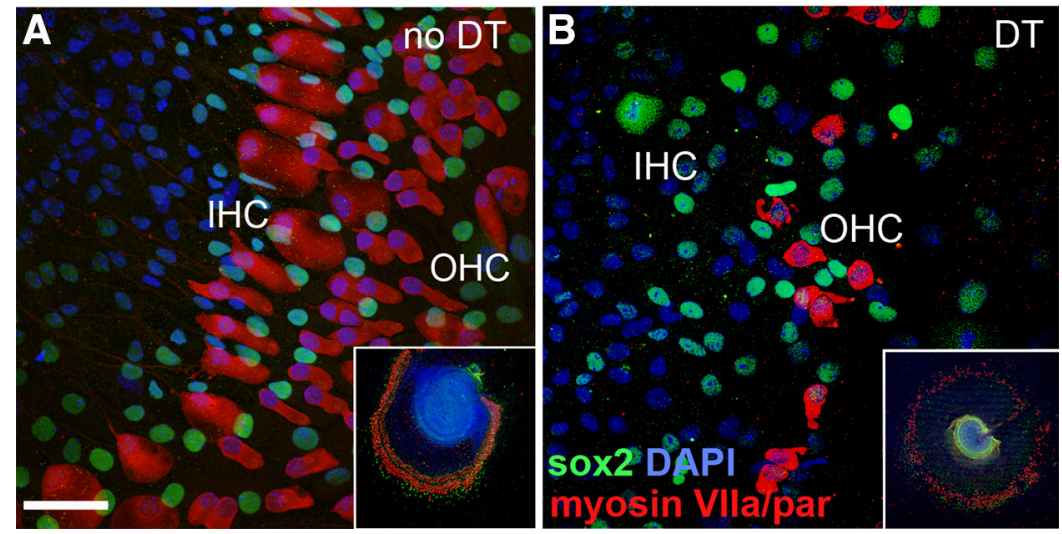

Figure 2. DT specifically eliminates hair cells in vitro in DTR mice. Cochlear explants were prepared from P2-P3 DTR and WT mice and subjected to either no treatment or DT administration $(25 \mathrm{ng} / \mathrm{ml})$ for $3 \mathrm{~d}$ in culture and then immediately fixed and subjected to immunolabeling. $\boldsymbol{A}$, Untreated explants from DTR mice have intact inner hair cells (IHCs) and outer hair cells $(\mathrm{OHCS})$ (red). $\boldsymbol{B}$, Treatment of explants from DTR mice with DT induces extensive loss of OHCs and complete loss of IHCs. There is no apparent impact of DT on supporting cells (green). Scale bar, $50 \mu \mathrm{m}$. Insets in $\boldsymbol{A}$ and $\boldsymbol{B}$ show low-power views of one representative turn of corresponding explant cultures.

were taken from three regions evenly spaced along the length of the sensory epithelium (middle of apex, middle of middle, and middle of basal turn) and converted to a linear density. In some cases, we collected 2 or 3 such lengths of epithelium in the same turn and averaged them to get a single number for each region of each cochlea. The areas were chosen strictly to be as close to the middle of the region with the caveat that they were free of dissection artifacts. Hair cells were counted in both WT littermates and DTR-injected mice. Data are presented as linear densities for inner hair cells, outer hair cells, and total hair cells. A minimum of three cochleas were counted and averaged for all data presented.

The means and descriptive statistics were calculated for percentage hair cells remaining. The data were loaded onto GraphPad Prism version 5.0a software. Analyses were performed using two-way ANOVA and Bonferroni post hoc comparisons. Results were considered significant when $p<0.05$.

Supporting cell counts. Supporting cell numbers were determined for mature-injected animals at 2 time points, 8 and $70 \mathrm{~d}$ after DT, using a nonbiased sampling method. Whole-mount preparations of apical turns taken from DT-injected ears ( $n=4 /$ time point) and normal control ears (WT injected with DT, DTR injected with saline, WT injected with saline, $n=2-4 /$ paradigm/time point) were labeled to detect organ of Corti support cells by labeling for Sox 2 and counterstained with DAPI. Sox2 labels the nuclei of all support cell subtypes and does not label sulcus cell nuclei (Oesterle et al., 2008). Tissue was viewed at $60 \times$ with an Olympus FV-1000 confocal laser scanning microscope. Each apical turn was typically subdivided into 3 equal regions (regions A-C) and each region was then subdivided into 4 smaller quadrants (quadrants 1-4). The quadrant to be imaged by confocal microscopy and quantitatively analyzed was randomly selected before beginning the data collection and was maintained for all 3 regions $(\mathrm{A}-\mathrm{C})$ of the apical turn. Each region imaged $\left(\right.$ area $=0.045 \mathrm{~mm}^{2}$ ) was recorded as vertical stack of confocal images ( $z$-series at $1 \mu \mathrm{m}$ increments) through the entire depth of the sensory epithelium. Density estimates of the number of Sox2-positive support cell nuclei were determined for each sampled region using the Cell Counter plug-in for ImageJ by dividing the number of Sox2positive support cells by the length of the sensory epithelium. Average numbers were determined for each organ and mean values were computed for each paradigm. Controls (WT injected with DT, DTR injected with saline, WT injected with saline) were grouped together because there were no reliable differences in numbers of Sox2-labeled cells.

Auditory brainstem response. Auditory brainstem responses (ABRs) were measured from several groups of mice. To assess the time course of hearing loss, all mice were P28-P42 at the time of DT or saline injection and $\sim 1 / 2$ were male. All mice were tested before the DT injection to establish premanipulation ABR thresholds. DTR mice receiving saline injections and WT mice receiving DT were again retested at $8 \mathrm{dpi}$. DTR mice were retested 1, 3, 5, 8 dpi. All groups had 3-5 mice. Mice were anesthetized (ketamine, $100 \mathrm{mg} / \mathrm{kg}$; xylazine, $5 \mathrm{mg} / \mathrm{kg}$, i.p.), placed on a heating pad to maintain body temperature near $37^{\circ} \mathrm{C}$, and placed in a sound-attenuating chamber. ABRs were recorded using standard subcutaneous needle electrodes with the positive and negative electrodes at the left temporal bone above the pinna and the vertex of the skull and the ground electrode in the thigh. Free-field pure tone stimuli were generated and $\mathrm{ABR}$ recordings were digitized using custom software. Tone pips were $5 \mathrm{~ms}$ in duration with $1 \mathrm{~ms}$ rise/fall times presented at a repe- 


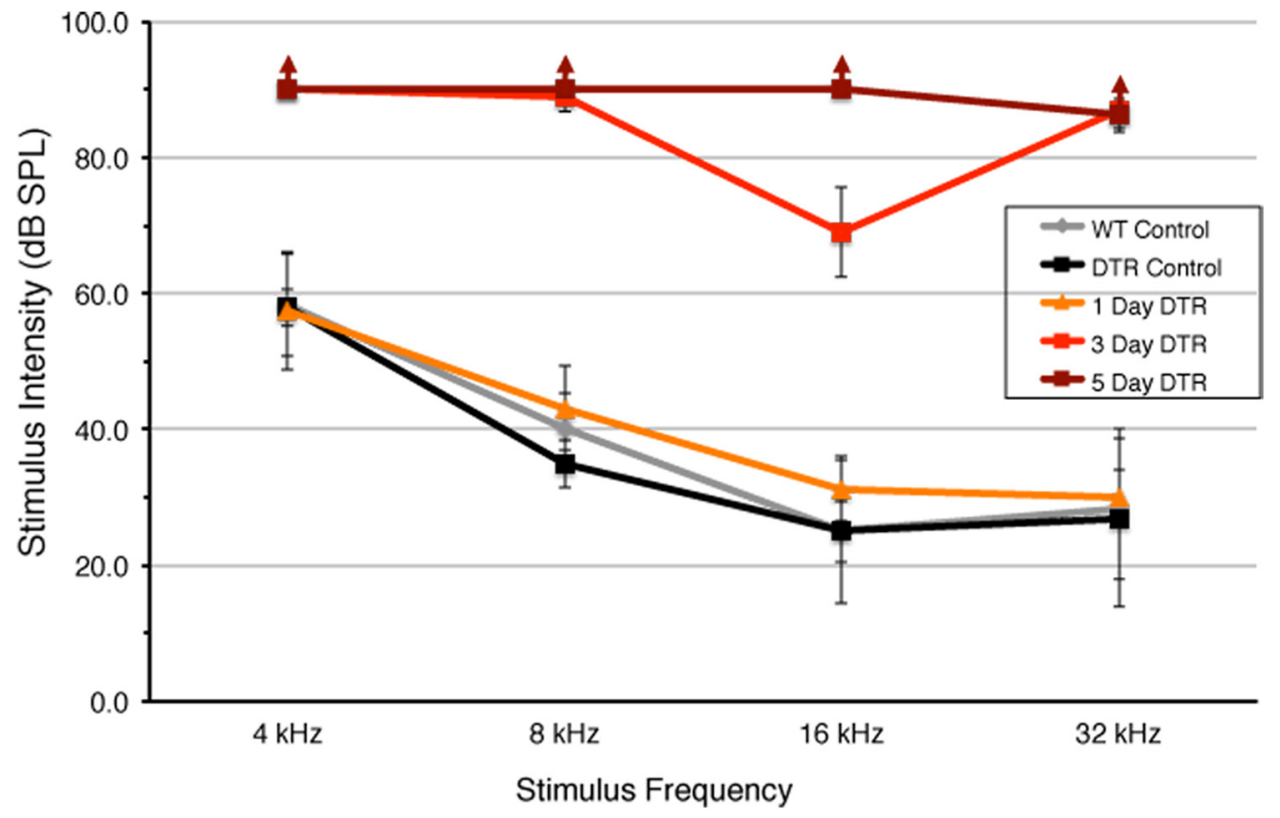

Figure 3. Hearing impairment in mature ( $>$ P28) DTR mice after injection of DT. ABRs were measured in mature mice at several times after injection of DT ( $25 \mathrm{ng} / \mathrm{g})$. DTR mice have normal ABR thresholds before DT injection (DTR control). Hearing loss is not apparent at 1 dpi in DTR mice. ABR thresholds are highly elevated by 3 dpi. By 5 dpi, mature mice did not respond to any stimulus frequency $(\uparrow)$, whereas these same mice have normal hearing thresholds before DT injection. WT mice have normal hearing $5 \mathrm{dpi}$ (WT control). Data are mean $\pm S D, n=3-5$ per group. Statistical analyses (two-way ANOVA followed by Bonferroni post hoc tests) yielded highly significant $(p<0.001)$ effect of groups and frequency as well as the interaction term due to significant hearing loss at 3 and 5 dpi in DTR mice. Difference between $1 \mathrm{~d}$ DTR animals and control groups is not significant $(p>0.10)$. Differences between 3 and $5 \mathrm{~d}$ DTR animals and all other groups are all highly significant at all frequencies $(p<0.01)$. Difference between 3 and 5 dpi DTR animals is significant at $16 \mathrm{kHz}(p<0.05)$.

tition rate of $19 / \mathrm{s}$. In addition, broadband clicks were presented at the beginning and end of each session to assess for any changes in the animal's condition. All stimuli were calibrated online at the beginning of each experiment with a calibrated probe microphone placed at the animal's ear canal. Neural responses were preamplified (100×, P15 amplifier; Grass Technologies), sent through an MA3 amplifier with an additional $20 \mathrm{~dB}$ post-preamp gain (Tucker Davis Technologies), band-pass filtered (100-3000 Hz; filter model 3550; KrohnHite), and digitized at $24.4 \mathrm{kHz}$. Responses were sampled in a $15 \mathrm{~ms}$ window (with a $5 \mathrm{~ms}$ stimulus onset delay). The threshold was defined as the lowest sound pressure level (SPL) in which a recognizable waveform was present and repeatable. Thresholds were determined at $4,8,16$, and $32 \mathrm{kHz}$ and for a broad-band click. For WT animals, stimuli were presented 500 times from 80 to $20 \mathrm{~dB}$ SPL in steps of 10 and then 1000 repetitions in steps of $5 \mathrm{~dB}$ SPL when approaching threshold. Near threshold, each series was repeated to determine the reliability of the waveform at the estimated threshold and $5 \mathrm{~dB}$ above and $10 \mathrm{~dB}$ below the estimated threshold. Stimuli for DTR mice were presented in the same way at 1000 repetitions. When animals appeared to be deaf, all frequencies were presented at intensities of 90 , and 70 $\mathrm{dB}$ SPL for 1000 repetitions to be assured of a complete hearing loss.

SGN counts. Two different methods were used to assess SGN survival. The first method used mice on the CBA/J background. One temporal bone from each animal was used for hair cell counts and, in most cases, the second temporal bone was decalcified, serially dehydrated in graded alcohols, embedded in epoxy resin, and serially sectioned $(1.5 \mu \mathrm{m})$ approximately parallel to the midmodiolar plane. Consecutive sections cochlea. Scale bar, $25 \mu \mathrm{m}$.
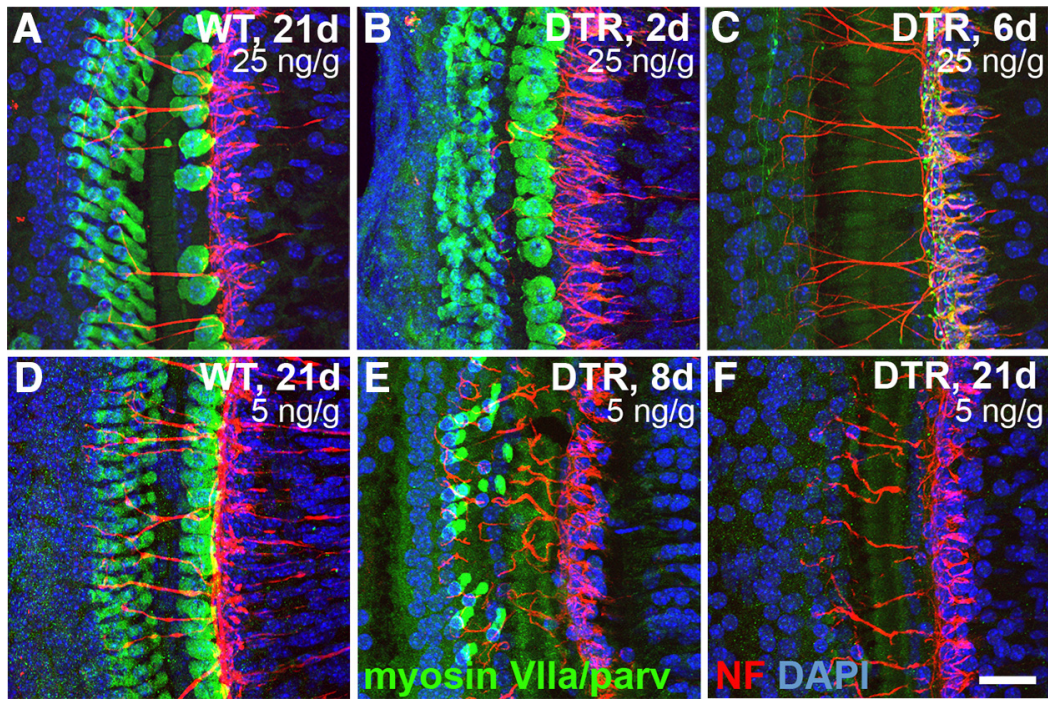

Figure 4. Cochlear hair cells are quickly lost in a dose-dependent manner after injection of DT in mature ( $\geq P 21)$ DTR mice. $A$, Hair cells (green) remain largely intact in WT littermates after injection of $25 \mathrm{ng} / \mathrm{g} D T$, even after long survival periods (shown here, $21 \mathrm{dpi}$ ). B, Hair cells are swollen and unhealthy looking in DTR mice after $25 \mathrm{ng} / \mathrm{g}$ DT injection as early as $2 \mathrm{dpi}$ (2d). C, By $6 \mathrm{dpi}$ (6d), essentially all inner and outer cochlear hair cells are gone. Terminal neurites labeled for neurofilaments (red) appear unaffected at short time points. D, Hair cells of WT mice are not affected in any observable way by a smaller dose of DT ( $5 \mathrm{ng} / \mathrm{g}$, shown here 21 dpi). $E, A t 5 \mathrm{ng} / \mathrm{g}$, hair cells are lost over a slower time course. All inner hair cells are gone, but a few outer hair cells remain $8 \mathrm{dpi}$. $\boldsymbol{F}$, By $21 \mathrm{dpi}$ with $5 \mathrm{ng} / \mathrm{g},<1 \%$ of hair cells remain and they are outer hair cells. All images here are from the basal turn of the

through the temporal bone were mounted on gelatin-coated slides, stained with toluidine blue, and coverslipped. Sections approximately every $50 \mu \mathrm{m}$ were used to image and count profiles of SGNs to sample along the area representing high, middle, and low frequency. An Axioplan 2ie upright microscope (Zeiss) equipped with a CoolSnap HQ camera (Photometrics) was used to view the sections. Images were collected with a $20 \times / 0.3 \mathrm{NA}$ Olympus apochromatic objective, $40 \times / 0.75$ 
NA Olympus apochromatic oil-immersion objective, or $100 \times / 1.40 \mathrm{NA}$ Olympus apochromatic oil-immersion objective. Images taken at the $20 \times$ magnification were used to delineate the contours of the apical, middle, and basal turns of Rosenthal's canal using ImageJ version 1.42a software. Rosenthal's canal was outlined by tracing along the bone surface on the inside of the canal. Images taken at the $40 \times$ magnification (tiled, when necessary) were used to count the number of type I and type II neuronal profiles separately. Type I neurons were distinguished from type II by the presence of myelin covering the cell body of the type I SGNs. From these total counts, neuronal profile density was calculated: the total number of neuronal profiles divided by the corresponding area of Rosenthal's canal. Density measurements were averaged across the apical, middle, and basal regions for each animal.

The second method for assessing SGN survival used mice on a C57BL/6J background. Isolated temporal bones were immersed in $0.1 \mathrm{M}$ EDTA to allow decalcification. Decalcified temporal bones were subjected to frozen sectioning parallel to mid-modiolar plane. Serial floating sections $(30 \mu \mathrm{m})$ were immunolabeled for neurofilament and tubulin proteins using standard immunofluorescence methods. Briefly, tissue was rinsed (PBS) and incubated at room temperature for $2 \mathrm{~h}$ in blocking solution ( $5 \%$ normal horse serum in $0.2 \%$ Triton X-100 in PBS). Sections were incubated overnight at room temperature with a combination of primary antibodies: mouse anti-neurofilament (Developmental Studies Hybridoma Bank, University of Iowa, 1:100) and mouse anti- $\beta$-III tubulin antibodies (Covance, 1:500) to label neurons. Specimens were then rinsed $5 \times$ in PBS and incubated for $2 \mathrm{~h}$ in secondary antibody conjugated to Alexa Flour 546 (1:500). All of the specimens were coverslipped using glycerol:PBS (9:1) as mounting media before microscopic imaging. Fluorescent imaging was performed using a Zeiss LSM 700 confocal microscope. $z$-series images at an interval of $0.77 \mu \mathrm{m}$ were obtained using a $20 \times$ objectives. Image processing and quantitative analysis was performed using Volocity 3D image analysis software (version 6.1.1; PerkinElmer). To report spiral ganglion cell body counts, neurofilamentand $\beta$-III tubulin-labeled cell bodies in Rosenthal's canal were counted from the maximum intensity projections of the section. Cell bodies counted from $4-5$ sections ( $30 \mu \mathrm{m}$ each) per cochlea were averaged and divided by the area of Rosenthal's canal from which the neurons were counted to get density measurements. Density measurements were averaged across the apical, middle, and basal regions for each animal.

$\mathrm{CN}$ neuron counts. Mice were terminally anesthetized with isoflurane and transcardially perfused with $4 \%$ paraformaldehyde. Brains were dissected from the same mice used to assess hair cell survival (described above) and from a group of long-term survival mice $(70+\mathrm{dpi})$. Tissue was postfixed in $4 \%$ paraformaldehyde at $4^{\circ} \mathrm{C}$ and stored in $\mathrm{PBS}$ at $4^{\circ} \mathrm{C}$ for a minimum of $24 \mathrm{~h}$, followed by croyprotection in $30 \%$ sucrose until it sank. Coronal sections of the brainstems were cut with a sliding freezing microtome at a thickness of $40 \mu \mathrm{m}$. Every fourth section was mounted onto gelatin-coated slides and allowed to dry. Slides were subsequently hydrated, stained with thionin, differentiated, cleared in ethanol and xylene, and coverslipped with DPX mounting medium.

Neurons were counted through the entire ventral CN (AVCN and PVCN, $6-10$ sections per mouse, depending on age). The brains included in this study were only those in which at least one side of the brainstem remained intact through the entire ventral $\mathrm{CN}$ in every mounted section.

Bright-field images for stereological methods were acquired on a Marianas imaging system controlled by Slidebook software, version 5.5 (Intelligent Imaging Innovations). This system included an Axiovert 200M inverted microscope (Zeiss) equipped with a motorized X, Y stage (Advanced Scientific) and a CoolSnap HQ cooled monochrome camera (Photometrics). The Slidebook stereology module was used for systematic random sampling and optical fractionator counting boxes (Gundersen et al., 1999). In brief, the entire VCN was outlined in a low-magnification montage and counting frames $(75 \times 75 \mu \mathrm{m})$ were spaced every $200 \mu \mathrm{m}$ on the dorsal/ventral plane and $150 \mu \mathrm{m}$ on the medial/lateral plane. A high-magnification $z$-stack was collected at each sampling location using a $63 \times / 1.2 \mathrm{NA}$ water-immersion objective and a $1 \mu \mathrm{m} z$-step. Guard zones of $3 \mu \mathrm{m}$ were placed at each edge. The NeuN antibody does not label all neurons in the AVCN, so this label was not used to quantify neuronal loss. Inclusion of thionin-stained cells as neurons was
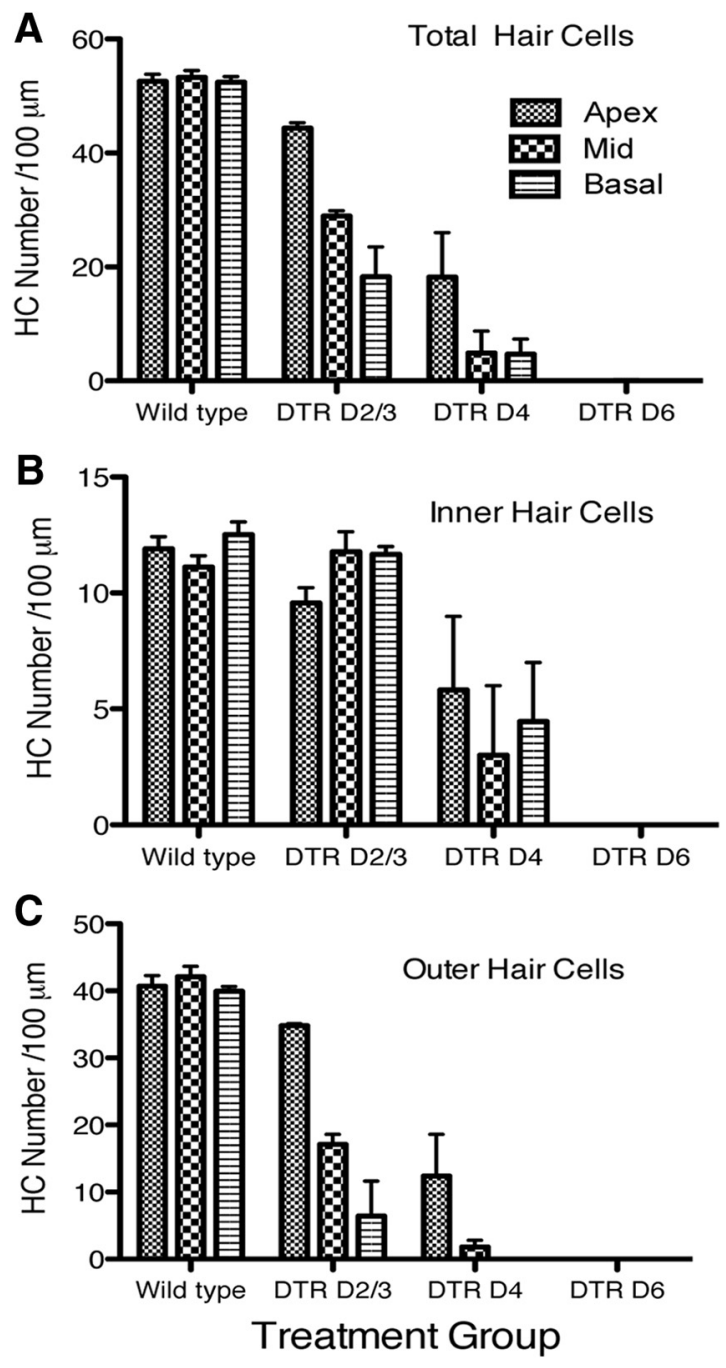

Figure 5. Quantification of hair cell density in each cochlear turn of mature (P21-P28) WT mice and DTR mice at $2-3,4$, and $6 \mathrm{dpi}$ ( $25 \mathrm{ng} / \mathrm{g}$, i.m.). $\boldsymbol{A}$, Total hair cells in each turn. $\boldsymbol{B}$, Inner hair cells. $C$, Outer hair cells. Ordinate scales are the same. Means + SEM are shown. Data were analyzed by two-way ANOVA and Bonferroni post hoc tests for total hair cells, inner hair cells, and outer hair cells separately. Major conclusions are that all hair cells are lost by $6 \mathrm{dpi}$, that outer hair cells are lost before inner hair cells $(p<0.001)$, and that basal outer hair cells are lost before apical outer hair cells $(p<0.01)$. WT mice injected with DT showed no significant changes in hair cell density over this period in any region (data not shown).

based on Nissl morphology, soma size, and presence of clearly defined nucleoli, as described previously (Mostafapour et al., 2000, 2002). Population estimates for the cochlear nuclei were calculated by multiplying the reciprocal of volume fraction by the summed neuronal counts for all sections. Sampling parameters were chosen so that the coefficient of error for every case was $<10 \%$ using the Gunderson $(m=1)$ Schmitz-Hof equation (Gundersen et al., 1999; Schmitz and Hof, 2000).

The cross-sectional area of individual neurons in the AVCN was measured from the stereology stacks by importing into Fiji 1.48p software. The area was determined by outlining the stained portion of the soma in the plane of maximum diameter. At least 50 neurons were measured per mouse.

Statistics. Means were calculated for hearing threshold, percent hair cell survival, neuron number, and neuron cross-sectional area. The data were analyzed by $t$ test or two-way ANOVA, where appropriate. Significant main effects or interactions were followed up using Bonferroni post hoc tests. Results were considered significant when $p<0$.05. Sample sizes were chosen on the basis of previous studies. All analyses were performed using GraphPad Prism version 5.0 for Mac OS X. 

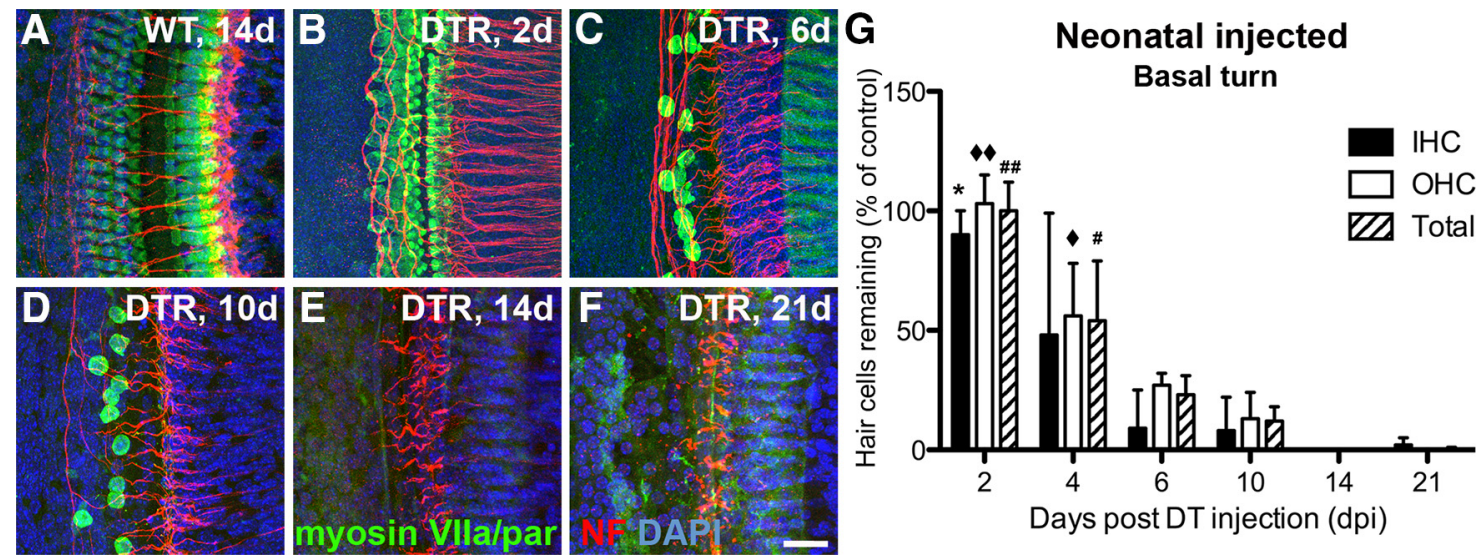

Figure 6. Cochlear hair cells are lost quickly after injection of DT in neonatal (P2) DTR mice. All data are from WT and DTR mice injected with DT at P2 with $4 \mathrm{ng} / \mathrm{g}$ body wt. $A$, Hair cells (green) remain largely intact in WT mice after injection of DT, even after long survival periods (shown here $14 \mathrm{dpi}$ ). $\boldsymbol{B}$, Hair cells are swollen and unhealthy looking in DTR mice as early as 2 dpi. $\boldsymbol{C}, \boldsymbol{D}$, At 6 and $10 \mathrm{dpi}$, extensive loss of both inner and outer hair cells is apparent, with almost complete loss of inner hair cells and the remaining outer hair cells appearing pathologically swollen. $\boldsymbol{E}, \boldsymbol{F}$, At 14 and $21 \mathrm{dpi}$, all hair cells are gone in the basal turn, but a few hair cells $(<5 \%)$ remain in more apical regions (Table 2). Nerve fibers from SGNs (red) are also markedly reduced after substantial hair cell loss, and this was especially apparent by $14 \mathrm{dpi}$ and beyond. Scale bar, $25 \mu \mathrm{m}$. G, Graph displays loss of inner, outer, and total hair cells in the middle of the basal turn of DTR mice. Data are mean \pm SEM ( $n=3$ cochleas from different mice). Statistical analyses (one-way ANOVA followed by Bonferroni post hoc tests) yielded significant effects of time dpi: * $p<0.05$ ( 2 vs 6,10 , 14 , and 21 dpi); $\diamond p<0.05$ (2 dpi vs all others); \#\# $p<0.05$ (2 dpi vs all others); $p<0.05$ (4 vs 6, 10, 14, and 21 dpi); \# $p<0.05$ (4 vs 6, 10, 14, and 21 dpi).

\section{Results}

To assist the reader's understanding of the timeline of experiments and treatments, a list and summary is provided in Table 1.

\section{Pou $4 f 3$ expression}

Pou4f3 expression is limited to hair cells in the sensory epithelium. When the cochleas of either WT or DTR mice were incubated with the Pou4f3 (Brn3c) antibody, selective labeling was apparent exclusively in the nuclei of inner and outer hair cells (Fig. 1A). On the basis of labeling intensity, inner hair cells appear to have greater expression of Pou4f3 than outer hair cells, but the nucleus of every hair cell in the cochlea was labeled (Fig. 1A, top inset). In neonatal mice (P2), some inner and outer hair cells in the apical region of the cochlea appeared to lack Pou $4 \mathrm{f3}$ protein, but by P5, all hair cells were labeled (data not shown). The selective expression in hair cells was confirmed with the Pou4f3-GFP reporter mouse, in which GFP could be seen throughout the entire hair cell instead of being limited to the nucleus (Fig. $1 A$, bottom inset).

For the interpretation of results on SGN and CN neurons reported below, it is also important to consider Pou $4 \mathrm{f} 3$ expression throughout the brain, particularly the auditory brainstem, and in the SGNs. We addressed this issue in several ways: (1) we examined the cochlea and brain in neonatal and mature mice from the Pou4f3 reporter mouse (see also Masuda et al., 2011); (2) we consulted the data on Pouff3 mRNA expression in mature and neonatal brain tissue in the Allen Brain Atlas (Lein et al., 2007; http://www.brain-map.org); and (3) we used RT-PCR to assess Pou4f3 mRNA expression in the cochlea and brainstem. Rigorous evaluation of these data in developing and mature brains confirms that no Pou $4 \mathrm{f} 3 \mathrm{mRNA}$ is expressed in the SGN or CN of the auditory brainstem, whereas Pou ff3 mRNA does seem to be expressed in other areas of the brain (e.g., striatum) and brainstem (e.g., olivary nuclei), consistent with data in the Allen Brain Atlas. Sections through the Pou4f3-GFP reporter mouse confirmed a lack of Pou $4 \mathrm{f} 3$ in the CN. Pou $4 \mathrm{f} 3$ mRNA expression is also limited to the cochleas compared with cochlear nuclei by quantitative RT-PCR expression analyses (data not shown).

\section{Hair cell survival in vitro}

To demonstrate the selective sensitivity of hair cells to DT, cochlear explants were prepared from both ears of $\mathrm{P} 2-\mathrm{P} 3$ pups from
Table 2. Mean ( \pm SD) percent of cochlear hair cells remaining (normalized to agematched controls) in each region of the cochlea after neonatal DT injection

\begin{tabular}{cccccc}
\hline Days post-DT & Apext tip & Apex & Mid & Base & Hook \\
\hline Inner hair cells & & & & & \\
2 & $65 \pm 11$ & $98 \pm 9$ & $103 \pm 17$ & $90 \pm 10$ & $95 \pm 5$ \\
4 & $15 \pm 5$ & $52 \pm 24$ & $86 \pm 6$ & $48 \pm 51$ & $14 \pm 16$ \\
6 & $40 \pm 28$ & $16 \pm 15$ & $23 \pm 16$ & $9 \pm 16$ & $7 \pm 8$ \\
10 & $36 \pm 19$ & $13 \pm 16$ & $17 \pm 14$ & $8 \pm 14$ & $5 \pm 8$ \\
14 & $30 \pm 9$ & $13 \pm 7$ & $1 \pm 2$ & 0 & 0 \\
21 & $26 \pm 7$ & $21 \pm 7$ & $12 \pm 7$ & $2 \pm 3$ & 0 \\
Outer hair cells & & & & & \\
2 & $*$ & $*$ & $75 \pm 30$ & $103 \pm 12$ & $101 \pm 5$ \\
4 & $6 \pm 6$ & $5 \pm 8$ & $32 \pm 19$ & $56 \pm 56$ & $57 \pm 21$ \\
6 & $*$ & $29 \pm 31$ & $64 \pm 19$ & $27 \pm 5$ & $42 \pm 56$ \\
10 & $0 \pm 1$ & $47 \pm 21$ & $71 \pm 7$ & $13 \pm 11$ & $9 \pm 4$ \\
14 & $3 \pm 5$ & 0 & 0 & 0 & 0 \\
21 & $7 \pm 6$ & $3 \pm 3$ & 0 & 0 & 0 \\
Total hair cells & & & & & \\
2 & $*$ & $*$ & $79 \pm 23$ & $100 \pm 12$ & $100 \pm 5$ \\
4 & $8 \pm 6$ & $14 \pm 3$ & $45 \pm 16$ & $54 \pm 25$ & $47 \pm 16$ \\
6 & $*$ & $27 \pm 26$ & $54 \pm 8$ & $23 \pm 8$ & $34 \pm 41$ \\
10 & $10 \pm 2$ & $39 \pm 13$ & $59 \pm 3$ & $12 \pm 6$ & $8 \pm 5$ \\
14 & $8 \pm 2$ & $36 \pm 23$ & $0 \pm 1$ & 0 & 0 \\
21 & $12 \pm 4$ & $7 \pm 1$ & $3 \pm 2$ & $0 \pm 1$ & 0 \\
\hline
\end{tabular}

*Loss of hair cell integrity and organization makes it difficult to count at this time point.

Pou $4 \mathrm{f3}^{+/ \mathrm{DTR}} \times \mathrm{WT}$ matings and cultured for $24 \mathrm{~h}$ in normal medium ( $n=30$ pups). After $24 \mathrm{~h}$, the explant culture from one ear was treated with DT $(25 \mathrm{ng} / \mathrm{ml})$ in the medium for $3 \mathrm{~d}$ and the other ear (control explant) was not treated with DT. Exposure to DT resulted in selective hair cell loss only in cultures from animals containing the Pou $43^{\text {DTR }}$ allele and only in the ear exposed to DT. Immunolabeling (Fig. 2) shows extensive loss of outer hair cells and complete loss of inner hair cells. The myosin VIIa staining that does remain is mostly associated with fragments of cells rather than whole labeled cells with a DAPI-stained nucleus. We observed no immediate qualitative changes in supporting cell number or morphology after $3 \mathrm{~d}$ of DT exposure in the cultures from DTR pups. DT treatment had no effect on hair cells in WT cochlear cultures. 

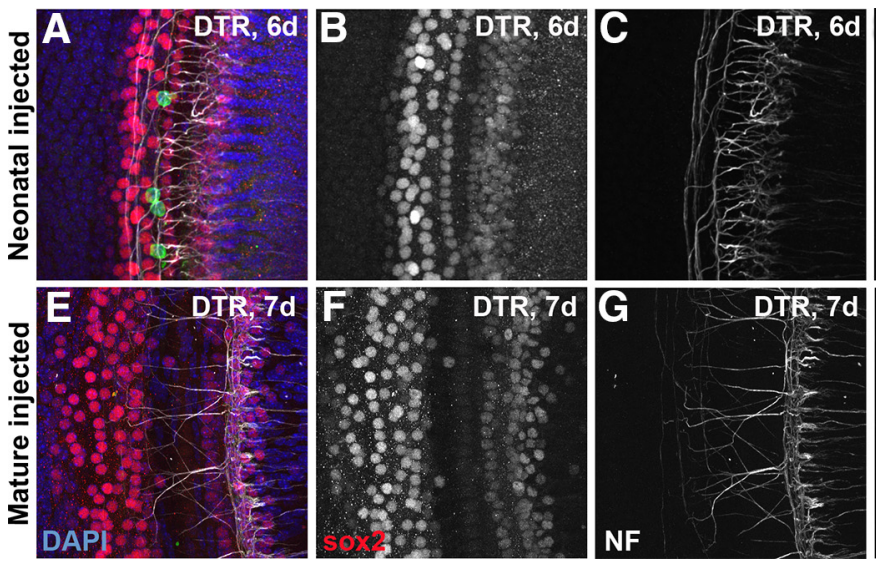

Figure 7. Effect of DT on supporting cells and peripheral neurites in the cochlea of DTR mice. $\boldsymbol{A}-\boldsymbol{C}$, Confocal images from a single confocal stack taken from a DTR mouse injected with DT on P2 and allowed to survive $6 \mathrm{~d}$ (middle turn shown here). $\boldsymbol{A}$, Merged image with Sox2 labeling of organ of Corti supporting cell nuclei (red), neurofilament reactivity (white), and DAPI nuclear counterstain (blue) and hair cells labeled with myosin VIla (green). Note that, whereas hair cells are virtually completely gone, supporting cells appear unaffected at short survival times. $\boldsymbol{B}$, Sox2 channel alone. $\boldsymbol{C}$, Neurofilament channel alone. $\boldsymbol{D}$, Neurofilament labeling in the same region from a DTR mouse injected with DT at P2, but allowed to survive $90 \mathrm{~d}$; note extensive loss of neurites and virtual absence of neurites crossing to the outer hair cell region. $\boldsymbol{E}-\mathbf{G}$, Confocal images from a single confocal stack taken from a mature DTR mouse injected with DT on P40 and allowed to survive $7 \mathrm{~d}$ (apical turn shown here). $\boldsymbol{E}$, Merged image labeled as in $\boldsymbol{A}$. $\boldsymbol{F}$, Sox2 channel alone. $\boldsymbol{G}$, Neurofilament channel alone. $\boldsymbol{H}$, Neurofilament labeling in the same region from a DTR mouse injected with DT at P40, but allowed to survive $75 \mathrm{~d}$; note extensive labeling of neurites that is essentially as dense as seen after only $7 \mathrm{~d}$ survival $(G)$ and as seen in WT mice. Also note normal numbers of neurites crossing to the outer hair cell region. These tissues were also labeled with an antibody against myosin VII for hair cells. Four hair cells (green) are seen in $\boldsymbol{A}$. All other hair cells have been eliminated by the DT. Scale bar, $25 \mu \mathrm{m}$.

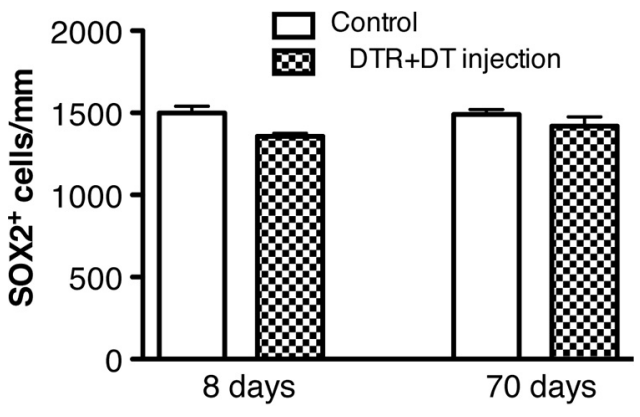

Time post-DT

Figure 8. Organ of Corti supporting cell density remains stable after DT injection in DTR mice. Supporting cells (Sox2 ${ }^{+}$cells) were quantified in the apical turn of experimental (DTR + DT) and control (WT injected with DT, DTR injected with saline, WT injected with saline) animals at 8 and 70 dpi using the nonbiased random sampling described in the Materials and Methods. Each data value represents the mean \pm SEM. Controls were grouped together because there were no reliable differences in numbers of Sox2-labeled cells. Note the absence of significant changes in support cell density after DT injection.

\section{Hearing impairment after injection of DT in vivo}

ABR thresholds were determined for pure tones $(4-32 \mathrm{kHz})$ in DTR mice and their WT littermates. Mature (P30-P35) DT (25 ng/g)-injected mice were tested 1, 3, and 5 dpi (Fig. 3). Both WT and DTR mice had normal ABR thresholds before DT injection (DTR control) and at $1 \mathrm{dpi}$ and were not statistically different from each other at any frequency. Impairment progressed rapidly, however; by $3 \mathrm{dpi}$, reliable ABRs were only evoked at intensities $>60 \mathrm{~dB}$ SPL and only at $16 \mathrm{kHz}$. By $5 \mathrm{dpi}$, none of the DTR mice showed an ABR at $90 \mathrm{~dB}$ SPL (the maximum intensity available) for all frequencies presented. ABR thresholds at 3 and 5 dpi were significantly impaired from WT, DTR control, and $1 \mathrm{~d}$ survival thresholds ( $p=0.0001$, two-way ANOVA, and $p<0.0001$, Bonferroni post hoc test, no interaction between time after injec-
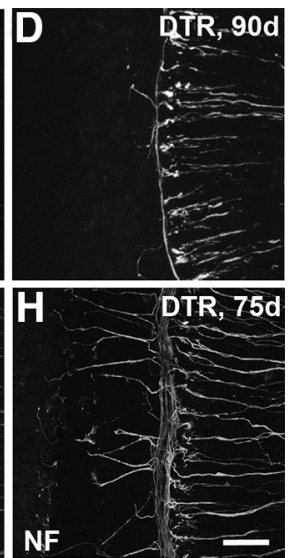

tion and frequency). Impairment persisted; data from mice 8 and 21 dpi were identical to data collected from mice 5 dpi and are therefore not shown in Figure 3. This functional deficit persists for as long as we have studied the animals, out to at least 3 months (see also Mahrt et al., 2013). These mice do not respond to any frequency or click at the highest intensity level. Data shown in Figure 3 were collected from mice on a CBA/J background, but a similar time course of thresholds changes was observed in mature mice on a C57BL/6J background.

A smaller dosage of DT in DTR mice $(10 \mathrm{ng} / \mathrm{g})$ delayed these functional deficits by a day or two. Mature DTR mice injected with only $5 \mathrm{ng} / \mathrm{g}$ DT failed to show an ABR to any frequency at $90 \mathrm{~dB}$ SPL by 8 dpi (data not shown).

\section{Time course of cochlear hair cell loss after injection of DT}

To begin determining the optimal dose of DT to ablate hair cells but maintain low mortality and minimal effects elsewhere in the body, several doses of DT ranging from 5 to $25 \mathrm{ng} / \mathrm{g}$ body weight were administered systemically to mature mice. In WT mice injected with DT at $25 \mathrm{ng} / \mathrm{g}$, most hair cells remain healthy (Fig. $4 A$ ), but an occasional inner hair cell was lost at this dose. In DTR mice injected at this dose, both inner and outer hair cells died quickly after the injection of DT. Representative examples are shown in Figure 4, $B$ and $C$, and numerical data are seen in Figure 5. Hair cells were present 2 dpi (Fig. 4B), but their morphology was obviously pathological. By 6 dpi, virtually all hair cells were gone (Figs. 4C, 5). This did not happen uniformly across the sensory epithelium. Loss was detected first mostly in the basal turn, and proceeded toward the apex. This result can be clearly seen in the outer hair cells (Fig. $5 C ; p<0.01$ ), but is not apparent in the inner hair cells (Fig. $5 B$ ). It is also readily apparent from Figure 5 that inner hair cells are lost more slowly than outer hair cells. At 6 dpi, we saw no viable appearing inner or outer hair cells in our samples contributing to Figure 5. In other animals, at day 6 , we have seen one or a few normal-appearing hair cells, especially in the apical tip, but these account for $<3 \%$ of the normal compliment of outer hair cells and do not appear in all animals. At 8 and $21 \mathrm{~d}$, we detected no viable appearing hair cells in tissue reacted with antibodies against myosin VIIa and parvalbumin in most cases, although occasionally a few $(<2 \%)$ outer hair cells remained.

A similar result occurred in DTR mice that received $15 \mathrm{ng} / \mathrm{g}$ DT (data not shown). At $21 \mathrm{dpi}$, there were no detectable hair cells at any location along the sensory epithelium ( $n=2$ mice). Less than $2 \%$ of hair cells remained at $8 \mathrm{dpi}$, and all hair cells remaining at this time were outer hair cells.

Hair cell loss occurred somewhat more slowly in the mature DTR mice that received $5 \mathrm{ng} / \mathrm{g}$ (Fig. $4 E, F$ ). In particular, at short survival times, more outer hair cells remained. At $8 \mathrm{dpi}$, there was a complete loss of inner hair cells (reflective of the strong Pou $4 \mathrm{f3}$ expression in the inner hair cells compared with outer hair cells), but many of the outer hair cells were spared (Fig. 4E). Less than $5 \%$ of outer hair cells were left in the basal half, and $>50 \%$ were left in the apical half at $8 \mathrm{dpi}$. By $21 \mathrm{dpi},<1 \%$ of 
hair cells remained (Fig. $4 F$ ). The few hair cells remaining were all outer hair cells located in the middle turn and basal hook regions.

As noted above, some hair cell loss occurred in WT mice after $25 \mathrm{ng} / \mathrm{g}$ DT injection (Fig. 4A). This loss was only seen in mature-injected mice and appeared to be dependent on both the dose of DT and the survival time. At 3 weeks after DT injection at this dosage in WT mice, hair cell loss primarily was limited to inner hair cells in the middle region of the sensory epithelium; no outer hair cell loss was seen in any region. This loss was reduced to $<2 \%$ in mice that received $15 \mathrm{ng} / \mathrm{g}$ and no hair cell loss was detected in mature WT mice that received $5 \mathrm{ng} / \mathrm{g}$ (Fig. 4D).

\section{Cochlear hair cell survival after neonatal injection of DT}

An important objective for our use of this model was to delete cochlear hair cells before hearing onset ( P12-P14; Rubel and Fritzsch, 2002). This required systemic injection of DT into early postnatal mice. For the data reported in this section, mice were injected at P2 $(4 \mathrm{ng} / \mathrm{g})$ to allow ample time for hair cell loss before the onset of hearing. In subsequent experiments, injections were made at P5 (5 ng/g). Waiting these additional $3 \mathrm{~d}$ increased animal survival of neonates but still killed hair cells completely before hearing onset in DTR mice. Data from mice injected with DT at P2 that survived for 2-21 dpi are shown in Figure 6 and Table 2. Images of hair cells are taken from the middle of the basal turn (Base) of the sensory epithelium (Fig. $6 A-F)$; the graph shows group data from the same region (Fig. $6 G$ ). Table 2 shows the percentage of inner and outer hair cells remaining in each $200 \mu \mathrm{m}$ segment of the cochlea [tip of the apex, middle of apical turn (Apex), middle of middle turn (Mid), middle of the basal turn (Base), and hook] at 2-21 dpi. In mice injected as neonates, cochlear hair cells began to look swollen and unhealthy as early as $2 \mathrm{dpi}$ (Fig. 6B). By $4 \mathrm{dpi}$, $\sim 1 / 2$ of the hair cells were gone in the basal half of the cochlea. At 6 and $10 \mathrm{dpi}$, a few hair cells were present, but the majority of both inner and outer hair cells were gone (Fig. $6 C, D$ ). Loss of inner hair cells was essentially complete by $14 \mathrm{dpi}$ (Fig. $6 \mathrm{E}$ ). As in the mature-injected mice, loss of hair cells was detected first in the basal hook and proceeded toward the apex (Table 2). Although complete hair cell loss was apparent in the basal turn at $21 \mathrm{dpi}$ (Fig. $6 F$ ), the apical region of the cochlea did not completely lose inner or outer hair cells, even at $21 \mathrm{dpi}$. As noted above, at P2, some outer hair cells do not show antibody reactivity to Pou4f3. We tentatively conclude that this is the reason for the persistence of the outer hair cells in the apical region.

When DT injections were delayed until P5, hair cell loss proceeded more quickly and to a greater extent. By $8 \mathrm{~d}$ after P5 injection, hair cells were virtually all gone. There were $<1 \%$ of hair cells remaining and those few cells were outer hair cells, again, typically located in the apical cochlea (data not shown).
WT
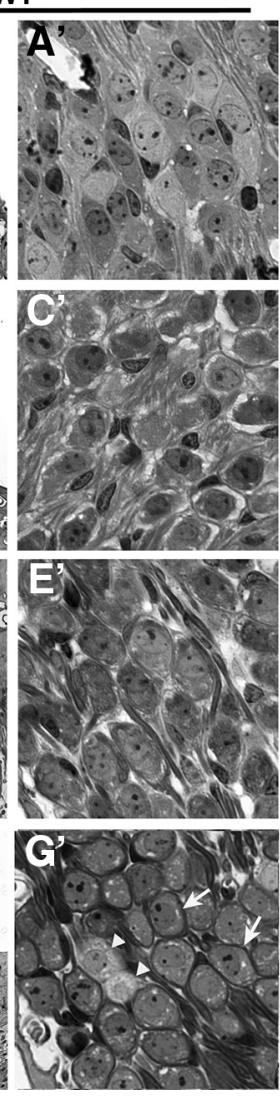

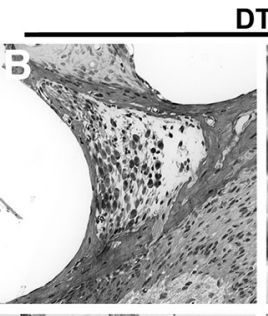

DTR
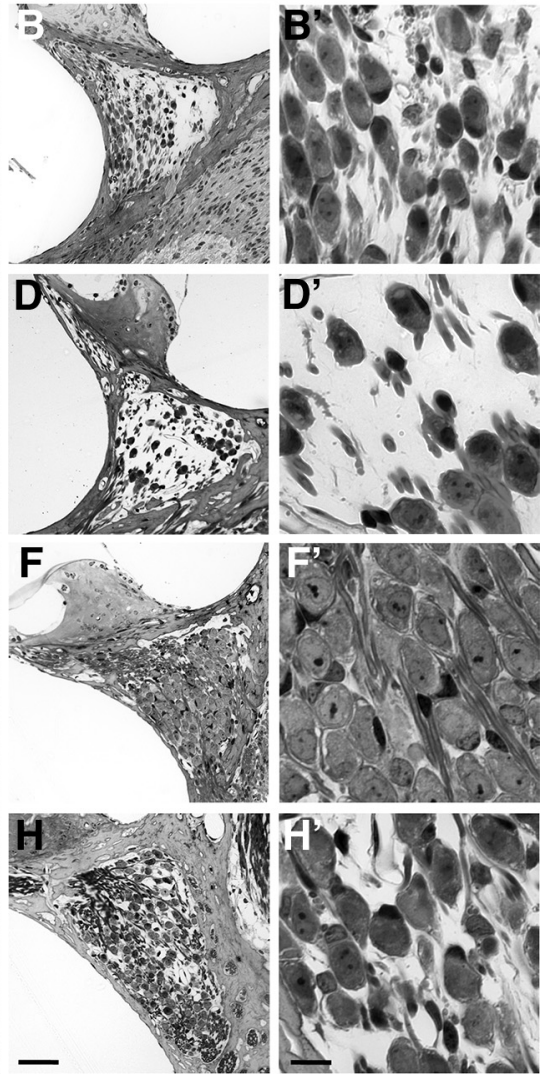

Figure 9. Age-dependent vulnerability of SGNs. Representative low-magnification $(\boldsymbol{A}-\boldsymbol{H})$ and high-magnification $\left(\boldsymbol{A}^{\prime}-\boldsymbol{H}^{\prime}\right)$ photomicrographs are shown for short ( $8 \mathrm{~d})$ and long ( $>70 \mathrm{~d}$ ) survival WT and DTR animals injected with DT as neonates or when mature (21 d). $\boldsymbol{A}, \boldsymbol{A}^{\prime}, \boldsymbol{C}, \boldsymbol{C}^{\prime}, \boldsymbol{E}, \boldsymbol{E}^{\prime}, \mathbf{G}, \boldsymbol{G}^{\prime}$, Low- and high-magnification images of SGN cell bodies remaining intact in WT mice after more mature age does not produce the same results. No loss is detectable after $8 \mathrm{~d}$ in mature DTR mice. $\boldsymbol{H}, \boldsymbol{H}^{\prime}, 0$ nly minor SGN loss myelin wrapping of cell bodies and type II SGNs without myelin-surrounding cell bodies are shown in $\boldsymbol{G}^{\prime}$ by white arrows and arrowheads, respectively. Scale bars: $\boldsymbol{A}-\boldsymbol{F}, 50 \mu \mathrm{m} ; \boldsymbol{A}^{\prime}-\boldsymbol{F}^{\prime}, 10 \mu \mathrm{m}$.

\section{No direct effect of DT on the supporting cells}

Although expression of Pou4f3 is selective to hair cells in the cochlea, we examined surrounding cell types to determine whether their integrity was directly affected by DT administration (Figs. 7, 8). Of most importance for this question are analyses during the time when the hair cells are dying. Analyses at later periods are interesting as well but address a different issue, that of trophic interactions between hair cells and supporting cells. Photomicrographs taken during the first week after injection of DT in both the neonatal (P2) and mature (P21) DTR mice showed healthyappearing supporting cells in both cases (Fig. $7 \mathrm{~B}, \mathrm{~F}$, respectively). This is at a time when the majority of hair cells were gone due to the injection of DT, as shown by the few green cells (myosin VIIa) remaining in Figure $7 A$ and the fact that none remained in Figure $7 E$. To provide a quantitative assessment of supporting cell survival, we counted the density of Sox2-positive cells in the organ of Corti of the apical turn in mature DTR mice injected with DT $(25 \mathrm{ng} / \mathrm{g})$ and control animals at 8 and 70 dpi (Fig. 8). These data supported our qualitative observations: the density of Sox2-positive cells in the organ of Corti were essentially equivalent between DTR animals injected with DT and control animals at 8 and $70 \mathrm{dpi}(p>0.10)$.

We carefully (albeit qualitatively) assessed the integrity of the nerve ending in the inner and outer hair cell regions using anti- 

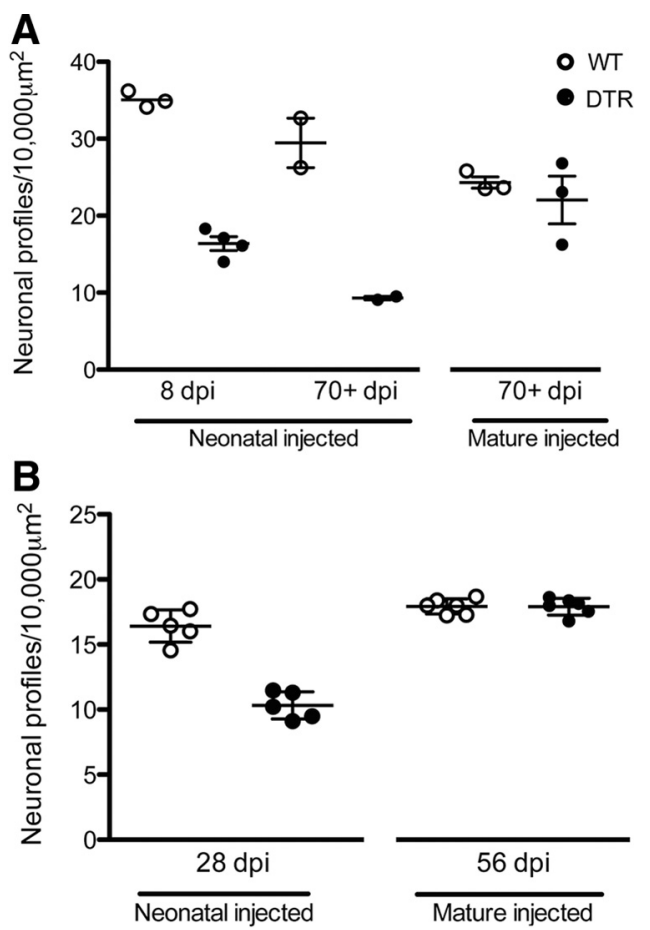

Figure 10. Critical period for SGN vulnerability to hair cell loss in DTR mice. A, SGNs are lost in DTR mice on a CBA/J background if they are injected with DT as neonates (P2-P5). After $8 \mathrm{~d}$, partial loss $(\sim 50 \%)$ is detectable and this progresses to $>66 \%$ loss by $70 \mathrm{dpi}$. In contrast, $<$ $10 \%$ loss is seen in mature ( $>$ P21) DTR mice compared with WT littermates even at $70+\mathrm{dpi}$ despite a complete loss of hair cells. Both groups of neonatally injected DTR mice have significantly reduced in SGN density $(p<0.001$; two-way ANOVA followed by Bonferroni post hoc test). DTR mice injected with DT at a more mature age have a significantly higher density of SG neurons than DTR mice injected as neonates ( $p<0.05$; one-way ANOVA followed by Bonferroni post hoc test). $\boldsymbol{B}$, Densities of SG neurons from mice on a (57BL/6J background assessed with neurofilament labeling. SGNs are lost in DTR mice only if they are injected with DT as neonates. There is a reduction in SGN density $28 \mathrm{~d}$ after neonatal DT injection of DTR mice, but not in age-matched WT mice nor in DTR mice in which DT injection was delayed until a more mature age ( $p<0.0001$; two-way ANOVA followed by Tukey's post hoc test).

bodies to neurofilament protein and/or parvalbumin. In neonatally injected DTR mice at $6 \mathrm{dpi}$, the numbers of axons were quite variable, with some animals showing a qualitatively normal pattern and some showing a clear reduction in the region of the inner hair cells (Fig. 7C). At longer survival times (e.g., $\geq 21 \mathrm{dpi}$ ) all neonatally injected cochleas showed a marked loss of axons in both the inner and outer hair cell regions (Fig. 7D). The survival of axons in the organ of Corti of cochleas from mature mice injected with DT was much more robust. Nerve fibers were still present in qualitatively normal numbers and healthy looking in all cases at both short (Fig. $7 G$ ) and long (Fig. $7 H$ ) survival times. It will be of great interest to further study the survival of these processes at a variety of survival times and determine the nature of the trophic interactions.

\section{Critical period for SGN survival}

SGN density was examined at the level of the cell bodies in Rosenthal's canal and in the terminal dendrites in the cochlea. Observations of the tissue (Fig. 9) and measurements of neuronal density (Fig. 10) both suggest that SGN cell body survival depends dramatically on the age when the DTR mice were injected with DT. When neonatal DTR mice were injected with DT, they showed profound loss of SGNs as early as $8 \mathrm{dpi}$ (Fig. 9B). This loss progressed such that only $\sim 30 \%$ of spiral ganglion cell bodies remained at $70 \mathrm{dpi}$ (Figs. 9D, 10A). WT mice injected with DT as neonates did not have any observable SGN cell body loss at any time point (Fig. 9A,C).

In stark contrast to the rapid and dramatic loss of SGNs in neonatally injected DTR mice, no detectable loss was seen at $8 \mathrm{dpi}$ in mice that were injected with DT as adults (Fig. 9F). By 70 dpi in mature DTR mice, the cell bodies of the SGNs showed minimal loss and appeared healthy (Fig. 9H) compared with age-matched WT littermates in Figure 9, $E$ and $G$, respectively. These qualitative observations are supported by measures of SGN cell body density and statistical comparisons shown in Figure $10 \mathrm{~A}$. Twoway ANOVA on neonatally injected animals revealed a highly significant main effect of genotype $(p<0.001)$ and no significant interaction terms. Within the neonatally injected animals, there was also a highly significant effect of genotype $(p<0.01)$.

SGNs were also examined in DTR mice on a C57BL/6J background. Using different histological methods and the neurofilament antibody to label SGN soma, similar results were observed as reported above. SGN density depended on the age at which DTR mice were injected with DT (Fig. 10B). Neonatal DTR mice had a profound decrease in the density $(\sim 44 \%)$ of spiral ganglion cell bodies after $28 \mathrm{dpi}$ at P7 $(p<0.01)$. In contrast, there was no detectable loss, even after twice that interval ( $56 \mathrm{~d}$ ), in mice that were injected with DT at a mature age.

These data suggest that, in addition to the critical period for neuronal survival in the $\mathrm{CN}$ that has been reported by many investigators in several species (Born and Rubel, 1985; Tierney et al., 1997; Mostafapour et al., 2000; Rubel and Fritzsch, 2002), the ability to selectively remove just the sensory hair cells reveals a critical period for SGNs during which their integrity requires the presence and/or activity derived from intact hair cells. Some caution should be exercised in the interpretation of these data. Although it is clear from the tissue that there is a rapid and profound loss of neurons in the neonatal DTR animals after DT exposure, one must be more cautious about the apparent lack of any change in the mature animals. Based on the small sample sizes and the fact that density, not the total number, of neuronal cell bodies was measured in our experiments, it is possible that some neuronal loss does normally occur in mature animals, but the number of cells that do die is relatively small and the time course is protracted compared with the situation in neonates.

Nerve terminals from the SGNs labeled by the neurofilament antibody can be seen in Figures 4, 6, and 7 We evaluated a large number of cochleas from survival times ranging from 2 to $100 \mathrm{~d}$. Once the hair cells start to die in neonatally injected animals, the nerve terminals in the cochlea became much sparser and had a retracted morphology. By $70+\mathrm{dpi}$, the axons terminating in the inner hair cell region were much less dense and the number of axons crossing the organ of Corti was sparse $(<10 \%$ remained) compared with WT mice. Qualitatively, some loss and retraction of peripheral dendrites was apparent in mature mice injected with DT, but this reaction was much less evident. In fact, the surprising result is that even $70+\mathrm{d}$ after complete hair cell loss, a dense pattern of labeled processes was apparent in the region previously occupied by inner hair cells; the number of radial fibers appeared comparable to that seen in WT mice.

\section{Critical period for neuronal death in the $\mathrm{CN}$ after injection of DT}

An important objective of this study was to determine whether the age-dependent timing and magnitude of neuronal loss in the $\mathrm{CN}$ of the brainstem depends entirely on the presence or loss of hair cells. Previous studies detailing this critical period have all used methods that damage the SGNs directly (e.g., surgical re- 

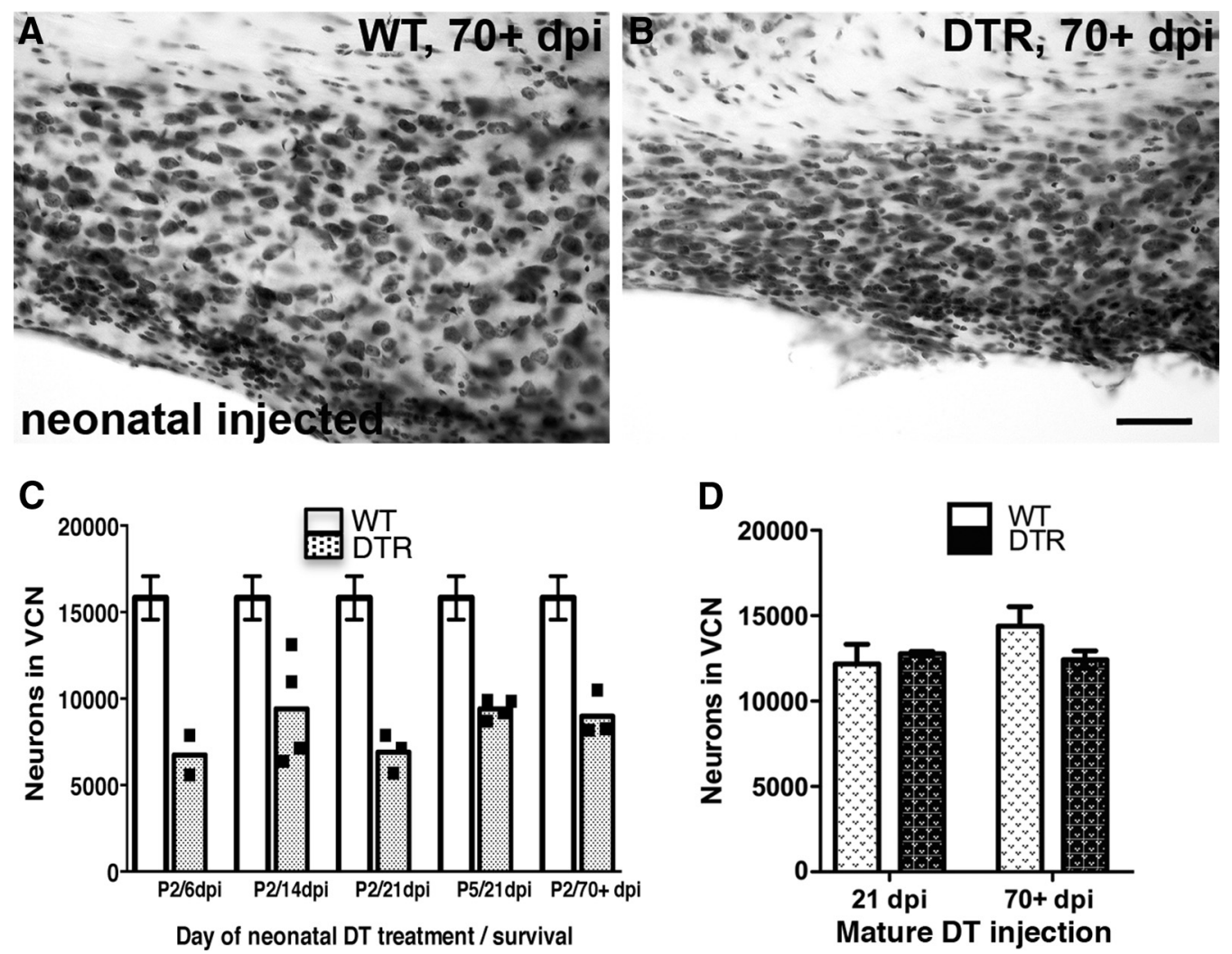

Figure 11. Critical period of neuronal vulnerability in the CN after hair cell loss. $A$, Neurons in the ventral CN ofWT remain intact at $70+d$ after neonatal (P2) injection of DT. $B$, DTR mice injected as neonates are vulnerable to neuronal loss in the ventral CN. Scale bar, $50 \mu \mathrm{m}$. C, Neuron counts in VCN of DTR mice injected with DT at P2 and allowed to survive for varying time intervals compared with the mean and SEM of all DTR injected WT mice. A one-way ANOVA comparing all the WT groups did not approach statistical significance $(p>0.26)$. The data from these 12 animals were used to provide a more accurate predictor of the normal cell numbers and that mean ( \pm 1 SEM) is shown as the open bars. The shaded bars show the mean and individual counts for 3-4 DTR DT-injected animals at each survival time. Neonatal $\mathrm{CN}$ neurons are very sensitive to the selective loss of hair cells compared with age-matched WT mice. Dramatic and significant neuron loss occurred as early as $6 \mathrm{dpi}(\boldsymbol{C})$ and persisted for as long as $70+\mathrm{dpi}$. Significant differences between WT and DTR mice injected with DT overall were seen (two-way ANOVA; $p<0.0001$ ) and were maintained at every time point (Bonferroni posthoctests; all $p<0.01$ ); no significant interaction was seen. Neuronal loss begins as early as 6 dpi in DTR mice injected as neonates and persists for at least 70 dpi. D, Dramatic neuronal loss is not evident in DTR mice injected as adults despite complete hair cell loss in the cochlea, even at $70+$ dpi. Data are mean \pm SEM, $n=2-5$. Two-way ANOVA failed to show any significant effects, although the small difference seen at the long survival time may warrant further study.

moval of the cochlea or ototoxic drug exposure) and other cell types in the inner ear. The benefit of the DTR mouse model is selective loss of hair cells without directly compromising SGNs, supporting cells, or the stria vascularis.

As shown in Figure 11D, right, when 21-d-old DTR mice were injected with DT $(25 \mathrm{ng} / \mathrm{g})$, there was no detectable CN neuron loss at $21 \mathrm{dpi}$. There appeared to be a slight loss after $70 \mathrm{~d}$, but statistical analyses of the mature injected data from these groups failed to reveal a significant two-way ANOVA. Perhaps longer survival times or a larger number of animals would reveal a small CN neuron loss, but such analyses remain to be completed.

In neonatal mice injected with DT at P2, however, the results are strikingly different. Figure $11 C$ shows neuron counts in VCN of DTR and WT mice injected with DT and allowed to survive for varying time intervals. A one-way ANOVA comparing all of the WT groups did not approach statistical significance $(p>0.26)$. The data from these 12 animals were used to provide a more accurate predictor of the normal cell numbers; the mean ( \pm 1 SEM) is shown as the open bars in Figure $11 B$. The shaded bars show the mean and individual counts for 3-4 DTR animals at each survival time. Neonatal $\mathrm{CN}$ neurons are very sensitive to the selective loss of hair cells compared with age-matched WT mice. Dramatic and significant neuron loss occurred as early as $6 \mathrm{dpi}($ Fig. $11 \mathrm{C}$ ) and persisted for as long as $70+$ dpi. Sig- nificant differences between WT and DTR mice injected with DT overall were seen (two-way ANOVA; $p<0.0001$ ) and maintained at every time point (Bonferroni post hoc tests; all $p<0.01)$ and no significant interaction was seen. $\mathrm{CN}$ cell counts in animals injected at P5 revealed essentially identical results and comparisons of neonatal versus mature DTR mice on a C57BL/6 background yielded the same overall results (data not shown).

\section{Neuronal size decreases after loss of hair cells}

The cross-sectional area of VCN neuronal soma were measured at selected times after injection in both neonatal and mature DTR and littermate WT mice exposed to DT. Previous studies suggest that neuronal size decreases after both deafferentation and elimination of presynaptic activity even when no neuronal loss occurs (Pasic and Rubel, 1989; Sie and Rubel, 1992). Here, we obtained similar results (Fig. 12). In mice injected with DT as neonates, a significant reduction in neuronal cross-sectional area was seen, but not immediately. The small difference seen at $6 \mathrm{dpi}$ was not significant, but the reduction in VCN neuron size was significant at $21 \mathrm{dpi}$ (2-way ANOVA, interaction $p=0.0024$; Bonferroni post hoc tests, $p<0.01)$. The effect in mature DTR mice was more subtle, but there was a highly significant reduction in neuron size long term $(p<0.001$; Fig. $12 C)$. 
A

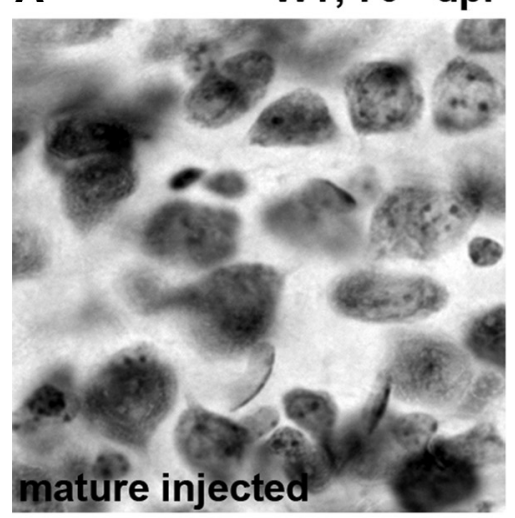

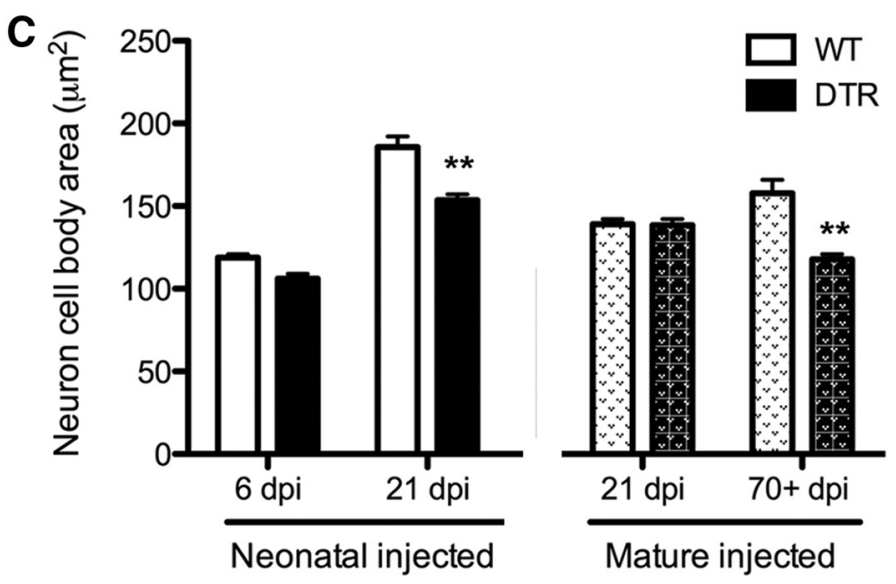

WT, 70+ dpi B

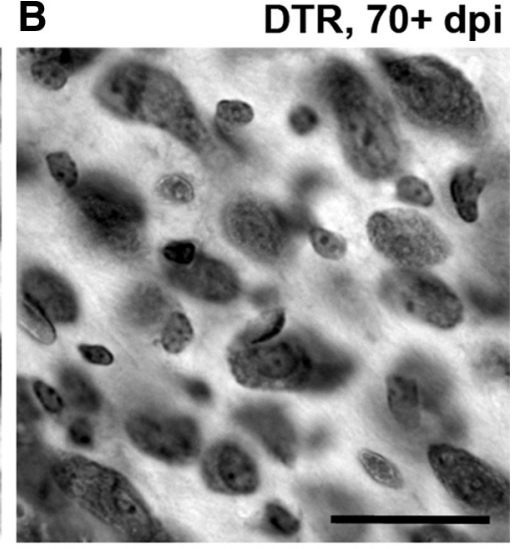

Figure 12. Neuronal cross-sectional area decreases slowly after cochlear hair cell loss. $\boldsymbol{A}, \boldsymbol{B}$, Photomicrographs of section through the middle region of the ventral CN of mature WT and DTR mouse, respectively, $70+$ dpi. Note that a small difference in neuron size is apparent, with soma area slightly smaller in DTR mouse CN. Scale bar, $25 \mu \mathrm{m}$. C, Cross-sectional area measurements of WT and DTR mice at various survival times. In neonatal mice injected with DT, neuronal size in the surviving neurons is significantly decreased by $21 \mathrm{dpi}$. A small, but significant, decrease is also detected when mature mice are injected with DT, but on a more delayed time course; Data are mean \pm SEM, $n=3-4 ;{ }^{* *} p<0.001$ (vs age-matched controls); two-way ANOVAs followed by Bonferroni post hoc tests.

\section{Discussion}

These studies provide three contributions. First, we describe and characterize a model system for investigating trophic interactions between cellular elements in the inner ear and for investigating the effects of hair cell viability on development and maintenance of neuronal populations in the CNS. Second, we describe a new critical period. In neonatal mice, input from intact hair cells, presumably largely inner hair cells, is required to maintain the full complement of SGNs. More than 50\% of the SGNs rapidly die when hair cells are eliminated in neonatal mice, whereas there appears to be relatively little or no SGN death when hair cells are eliminated in mature mice. Finally, we have used this mouse model to test the hypothesis that hair cell integrity is required for the trophic relationship between the ear and neurons of the developing CN. Removing hair cells in neonatal mice results in rapid and profound transneuronal degeneration in the ventral $\mathrm{CN}$, comparable to that seen with destruction of the entire cochlea, without causing direct damage to the supporting cells. The same manipulation in mature mice does not result in neuronal loss.

\section{Pou4f3 ${ }^{+/ D T R}$ mouse model}

Beneficial characteristics of the DTR mouse model are temporal control over hair cell loss and speed, specificity, and completeness

of hair cell removal. The presence of the hDTR sensitizes cells to DT without affecting surrounding cell types (Palmiter, 2001; Saito et al., 2001). Direct effects of systemic DT administration in the inner ear appear limited to the hair cells in the cochlea and vestibular epithelium of the DTR mice (Golub et al., 2012). Administration of DT in the first few postnatal days ablates the hair cells before the onset of hearing. Hair cell ablation can also be delayed until maturity. We show virtually complete $(>95 \%)$ hair cell loss and complete loss of ABR by $6 \mathrm{~d}$ after DT injection in mature mice and near complete loss of hair cells in the first week when DT is administered to neonates. In neonates and mature mice, the hearing loss and hair cell loss appears to be permanent (Mahrt et al., 2013).

There are several other experimental preparations for creating hair cell loss in mice, all of which have been beneficial in adding to our understanding of the mechanisms and consequences of hair cell loss. However, confounding factors limit interpretations of experimental outcomes related to studies of afferent regulation of CNS neurons or hair cell regeneration. When mature mice with a targeted deletion of the high-affinity thiamine transporter gene (Slc19a2) are maintained on a low thiamine diet, they suffer robust loss of inner and outer hair cells and impairments in hearing (Liberman et al., 2006; Zilberstein et al., 2012). Although this is a useful model with which to study hair cell loss in a mature animal, it takes several weeks to induce maximum hair cell loss and is therefore not appropriate for our studies on developmental regulation and critical periods. A second genetic model carries a hair-cell-specific (Atoh1-CreER) allele that allows inducible expression of DT fragment A (Burns et al., 2012). This model only allows ablation of hair cells in embryos or animals early in the postnatal period because Atoh 1 expression turns off shortly after birth. Therefore, it is not useful for comparisons between deafening in immature and mature animals. Finally, many studies have used ototoxic compounds (such as aminoglycosides) or high-intensity noise exposure. Although hair cells show greater vulnerability to these treatments than surrounding cells, both ototoxic drugs and noise exposure are toxic to other components of the inner ear, including ganglion cells, stria vascularis, and supporting cells, when exposures are at a level that results in complete, or nearly complete, loss of hair cells and profound hearing loss (Carlier and Pujol, 1980; Wang et al., 2002; Hirose and Liberman, 2003; Oesterle et al., 2008; Oesterle and Campbell, 2009). Furthermore, as highlighted by Murillo-Cuesta et al. (2010), it is difficult to find two studies that used the same protocol of aminoglycoside treatment in mice. Even local application of ototoxic agents has the problem of enormous intersubject variability (Heydt et al., 2004). 


\section{Critical period for SGN survival}

SGN function and survival during development and after potentially ototoxic insults has been of considerable interest due to their importance related to medical and surgical treatments for hearing loss. The large literature on neurotrophin- and activitymediated developmental events, including survival of SGNs, has been reviewed recently (Leake et al., 2008; Green et al., 2012; Leake et al., 2013; Moser et al., 2013; Seyyedi et al., 2013). Most studies have used cats or rodents and produced cochlear insults early in development to study SGNs after application of neurotrophins and/or electrical stimulation. In their "control groups," in which neonatal animals are treated with aminoglycosides or aminoglycosides in conjunction with diuretics to kill hair cells, SGN loss is apparent shortly after hair cell loss (Leake et al., 1997). This loss continues to increase for months or years (Leake and Hradek, 1988). Fewer studies have focused on SGN survival after hair cell injury in adult animals. In one thorough series of studies, Kujawa and colleagues (Kujawa and Liberman, 2009; Lin et al., 2011) have followed changes in SGN axon density and SGN survival after acoustic overstimulation. They observed rapid loss of synapses and dramatic decreases in peripheral axon density within days. However, loss of SGN cell bodies appears quite small and occurred over a time course of months to years. These results are consistent with the results of Zilberstein et al. (2012) showing that elimination of inner hair cells does not result in SGN death measured after 3 months.

The pattern of SGN loss seen in the Pou $43^{+/ D T R}$ mice provides convincing experimental evidence that there exists a critical developmental period in mice where SGN survival is dependent on intact hair cells. The precise age limits to the beginning and end of this period are yet to be determined, but hair cell elimination before the onset of hearing results in rapid and profound degeneration of SGNs, whereas even total elimination of hair cells in mature animals results in relatively little or no SGN death. These results, if replicated in other vertebrates, may have important implications for habilitation and rehabilitation strategies and provide a new useful system for investigating the molecular mechanisms underlying critical periods in sensory system development. The fact that this critical period is also a time of glial cell maturation (Dinh et al., 2014) could be indicative of an underlying mechanism of vulnerability.

\section{Critical period for $\mathrm{CN}$ neuron survival}

A plethora of data support the conclusion that hearing loss resulting from elimination of the cochlea in birds or mammals causes rapid and profound $\mathrm{CN}$ neuronal degeneration in young animals, but usually not in mature animals subjected to the same surgical procedures (Rubel and Fritzsch, 2002; Harris and Rubel, 2006). In mice, this critical period ends by P14, about the time when mice begin to hear external acoustic signals. From this literature, it is difficult to ascertain the origin of signals initiating the transneuronal degeneration in young animals and whether the developmental change in vulnerability rests with presynaptic elements (e.g., SGN axons) or the postsynaptic cells in the CN. A few studies have addressed these issues with activity blockers introduced into the inner ear (Born and Rubel, 1988; Pasic and Rubel, 1989; Sie and Rubel, 1992), but animal welfare concerns prevent maintaining this manipulation for the more prolonged period required for transneuronal degeneration. Results presented here indicate that the timing and magnitude of neuronal loss and associated changes in the $\mathrm{CN}$ after hair cell elimination using the DTR mouse are essentially identical to results after removal of the cochlea and SGN in mice and gerbils (Trune, 1982;
Hashisaki and Rubel, 1989; Tierney et al., 1997; Mostafapour et al., 2000; Harris and Rubel, 2006).

In contrast to most earlier studies in which subjects received a unilateral cochlear removal, hair cell loss in the DTR mouse model is bilateral and an internal control is lacking. This required the use of stereology to make comparisons between animals. Some neurons are small and indistinguishable from glial cells using a Nissl stain. As a result, there may have been a slightly lower estimate of neuron population in the mouse $\mathrm{CN}$ than reported previously (Idrizbegovic et al., 2001). Regardless, a very robust critical period was evident in the DTR mouse.

It is tempting to conclude from our data that the SGN neuron loss is directly responsible for the critical period observed in the $\mathrm{CN}$; after hair cell elimination in neonates, SGNs and their target neurons die, whereas both cell types live after hair cell elimination in mature animals. This conclusion is proven false, however, by the plethora of evidence that $\mathrm{CN}$ neurons do not die in mature mammals after complete removal of the cochlea and SGN (Tierney et al., 1997; Mostafapour et al., 2000). Conversely, it remains to be determined whether $\mathrm{CN}$ neurons would be resistant to hair cell loss in neonates if SGNs were preserved entirely.

\section{References}

Baldi A, Calia E, Ciampini A, Riccio M, Vetuschi A, Persico AM, Keller F (2000) Deafferentation-induced apoptosis of neurons in thalamic somatosensory nuclei of the newborn rat: critical period and rescue from cell death by peripherally applied neurotrophins. Eur J Neurosci 12:22812290. CrossRef Medline

Born DE, Rubel EW (1985) Afferent influences on brain stem auditory nuclei of the chicken: neuron number and size following cochlea removal. J Comp Neurol 231:435-445. CrossRef Medline

Born DE, Rubel EW (1988) Afferent influences on brain stem auditory nuclei of the chicken: presynaptic action potentials regulate protein synthesis in nucleus magnocellularis neurons. J Neurosci 8:901-919. Medline

Burns JC, Cox BC, Thiede BR, Zuo J, Corwin JT (2012) In vivo proliferative regeneration of balance hair cells in newborn mice. J Neurosci 32:65706577. CrossRef Medline

Carlier E, Pujol R (1980) Supra-normal sensitivity to ototoxic antibiotic of the developing rat cochlea. Arch Otorhinolaryngol 226:129-133. CrossRef Medline

Dinh ML, Koppel SJ, Korn MJ, Cramer KS (2014) Distribution of glial cells in the auditory brainstem: normal development and effects of unilateral lesion. Neuroscience 278:237-252. CrossRef Medline

Erkman L, McEvilly RJ, Luo L, Ryan AK, Hooshmand F, O'Connell SM, Keithley EM, Rapaport DH, Ryan AF, Rosenfeld MG (1996) Role of transcription factors Brn-3.1 and Brn-3.2 in auditory and visual system development. Nature 381:603-606. CrossRef Medline

Frazier-Cierpial L, Brunjes PC (1989) Early postnatal cellular proliferation and survival in the olfactory bulb and rostral migratory stream of normal and unilaterally odor-deprived rats. J Comp Neurol 289:481492. CrossRef Medline

Galli-Resta L, Ensini M, Fusco E, Gravina A, Margheritti B (1993) Afferent spontaneous electrical activity promotes the survival of target cells in the developing retinotectal system of the rat. J Neurosci 13:243-250. Medline

Golub JS, Tong L, Ngyuen TB, Hume CR, Palmiter RD, Rubel EW, Stone JS (2012) Hair cell replacement in adult mouse utricles after targeted ablation of hair cells with diphtheria toxin. J Neurosci 32:15093-15105. CrossRef Medline

Green SH, Bailey E, Wang Q, Davis RL (2012) The Trk A, B, C's of neurotrophins in the cochlea. Anat Rec (Hoboken) 295:1877-1895. CrossRef Medline

Grubb MS, Thompson ID (2004) The influence of early experience on the development of sensory systems. Curr Opin Neurobiol 14:503-512. CrossRef Medline

Guillery RW (1973) Quantitative studies of transneuronal atrophy in the dorsal lateral geniculate nucleus of cats and kittens. J Comp Neurol 149: 423-438. CrossRef Medline

Gundersen HJ, Jensen EB, Kiêu K, Nielsen J (1999) The efficiency of 
systematic sampling in stereology-reconsidered. J Microsc 193:199211. CrossRef Medline

Harris JA, Rubel EW (2006) Afferent regulation of neuron number in the cochlear nucleus: cellular and molecular analyses of a critical period. Hear Res 216-217:127-137. Medline

Hashisaki GT, Rubel EW (1989) Effects of unilateral cochlea removal on anteroventral cochlear nucleus neurons in developing gerbils. J Comp Neurol 283:5-73. CrossRef Medline

Hebb DO (1949) The organization of behavior: a neuropsychological theory. New York: Wiley.

Heydt JL, Cunningham LL, Rubel EW, Coltrera MD (2004) Round window gentamicin application: an inner ear hair cell damage protocol for the mouse. Hear Res 192:65-74. CrossRef Medline

Hirose K, Liberman MC (2003) Lateral wall histopathology and endocochlear potential in the noise-damaged mouse cochlea. J Assoc Res Otolaryngol 4:339-352. CrossRef Medline

Idrizbegovic E, Canlon B, Bross LS, Willott JF, Bogdanovic N (2001) The total number of neurons and calcium binding protein positive neurons during aging in the cochlear nucleus of $\mathrm{CBA} / \mathrm{CaJ}$ mice: a quantitative study. Hear Res 158:102-115. CrossRef Medline

Kalil R (1980) Quantitative study of the effects of monocular enucleation and deprivation on cell growth in the dorsal lateral geniculate nucleus of the cat. J Comp Neurol 189:483-524. CrossRef Medline

Kujawa SG, Liberman MC (2009) Adding insult to injury: cochlear nerve degeneration after "temporary" noise-induced hearing loss. J Neurosci 29:14077-14085. CrossRef Medline

Lauer AM, Connelly CJ, Graham H, Ryugo DK (2013) Morphological characterization of bushy cells and their inputs in the laboratory mouse (Mus musculus) anteroventral cochlear nucleus. PLoS One 8:e73308. CrossRef Medline

Leake PA, Hradek GT (1988) Cochlear pathology of long term neomycin induced deafness in cats. Hear Res 33:11-33. CrossRef Medline

Leake PA, Kuntz AL, Moore CM, Chambers PL (1997) Cochlear pathology induced by aminoglycoside ototoxicity during postnatal maturation in cats. Hear Res 113:117-132. CrossRef Medline

Leake PA, Stakhovskaya O, Hradek GT, Hetherington AM (2008) Factors influencing neurotrophic effects of electrical stimulation in the deafened developing auditory system. Hear Res 242:86-99. CrossRef Medline

Leake PA, Stakhovskaya O, Hetherington A, Rebscher SJ, Bonham B (2013) Effects of brain-derived neurotrophic factor (BDNF) and electrical stimulation on survival and function of cochlear spiral ganglion neurons in deafened, developing cats. J Assoc Res Otolaryngol 14:187-211. CrossRef Medline

Lein ES, Hawrylycz MJ, Ao N, Ayres M, Bensinger A, Bernard A, Boe AF, Boguski MS, Brockway KS, Byrnes EJ, Chen L, Chen L, Chen TM, Chin MC, Chong J, Crook BE, Czaplinska A, Dang CN, Datta S, Dee NR, et al. (2007) Genome-wide atlas of gene expression in the adult mouse brain. Nature 445:168-176. CrossRef Medline

Levi-Montalcini R (1949) The development of the acoustico-vestibular centres in the chick embryo in the absence of the afferent root fibers and of descending fiber tracts. J Comp Neurol 91:209-241. CrossRef Medline

Liberman MC, Tartaglini E, Fleming JC, Neufeld EJ (2006) Deletion of SLC19A2, the high affinity thiamine transporter, causes selective inner hair cell loss and an auditory neuropathy phenotype. J Assoc Res Otolaryngol 7:211-217. CrossRef Medline

Lin HW, Furman AC, Kujawa SG, Liberman MC (2011) Primary neural degeneration in the Guinea pig cochlea after reversible noise-induced threshold shift. J Assoc Res Otolaryngol 12:605-616. CrossRef Medline

Mahrt EJ, Perkel DJ, Tong L, Rubel EW, Portfors CV (2013) Engineered deafness reveals that mouse courtship vocalizations do not require auditory experience. J Neurosci 33:5573-5583. CrossRef Medline

Masuda M, Dulon D, Pak K, Mullen LM, Li Y, Erkman L, Ryan AF (2011) Regulation of POU4F3 gene expression in hair cells by $5^{\prime} \mathrm{DNA}$ in mice. Neuroscience 197:48-64. CrossRef Medline

Mitamura T, Higashiyama S, Taniguchi N, Klagsbrun M, Mekada E (1995) Diphtheria toxin binds to the epidermal growth factor (EGF)-like domain of human heparin-binding EGF-like growth factor/diphtheria toxin receptor and inhibits specifically its mitogenic activity. J Biol Chem 270: 1015-1019. CrossRef Medline
Moser T, Predoehl F, Starr A (2013) Review of hair cell synapse defects in sensorineural hearing impairment. Otol Neurotol 34:995-1004. CrossRef Medline

Mostafapour SP, Cochran SL, Del Puerto NM, Rubel EW (2000) Patterns of cell death in mouse anteroventral cochlear nucleus neurons after unilateral cochlea removal. J Comp Neurol 426:561-571. CrossRef Medline

Mostafapour SP, Del Puerto NM, Rubel EW (2002) bcl-2 Overexpression eliminates deprivation-induced cell death of brainstem auditory neurons. J Neurosci 22:4670-4674. Medline

Murillo-Cuesta S, Contreras J, Cediel R, Varela-Nieto I (2010) Comparison of different aminoglycoside antibiotic treatments to refine ototoxicity studies in adult mice. Lab Anim 44:124-131. CrossRef Medline

Oesterle EC, Campbell S (2009) Supporting cell characteristics in longdeafened aged mouse ears. J Assoc Res Otolaryngol 10:525-544. CrossRef Medline

Oesterle EC, Campbell S, Taylor RR, Forge A, Hume CR (2008) Sox2 and JAGGED1 expression in normal and drug-damaged adult mouse inner ear. J Assoc Res Otolaryngol 9:65-89. CrossRef Medline

Palmiter R (2001) Interrogation by toxin. Nat Biotechnol 19:731-732. CrossRef Medline

Parks, T.N., and Rubel, E.W (2004) Overview: development and plasticity of the central auditory system. In: Plasticity of the auditory system (Parks TN, Rubel EW, Popper AN, Fay RR, eds), pp 1-7. New York: Springer.

Pasic TR, Rubel EW (1989) Rapid changes in cochlear nucleus cell size following blockade of auditory nerve electrical activity in gerbils. J Comp Neurol 283:474-480. CrossRef Medline

Rubel EW, Fritzsch B (2002) Auditory system development: primary auditory neurons and their targets. Annu Rev Neurosci 25:51-101. CrossRef Medline

Ryugo DK, Parks TN (2003) Primary innervation of the avian and mammalian cochlear nucleus. Brain Res Bull 60:435-456. CrossRef Medline

Saito M, Iwawaki T, Taya C, Yonekawa H, Noda M, Inui Y, Mekada E, Kimata Y, Tsuru A, Kohno K (2001) Diphtheria toxin receptor-mediated conditional and targeted cell ablation in transgenic mice. Nat Biotechnol 19:746-750. CrossRef Medline

Sanes DH, Woolley SM (2011) A behavioral framework to guide research on central auditory development and plasticity. Neuron 72:912-929. CrossRef Medline

Schmitz C, Hof PR (2000) Recommendations for straightforward and rigorous methods of counting neurons based on a computer simulation approach. J Chem Neuroanat 20:93-114. CrossRef Medline

Seyyedi M, Eddington DK, Nadol JB Jr (2013) Effect of monopolar and bipolar electric stimulation on survival and size of human spiral ganglion cells as studied by postmortem histopathology. Hear Res 302:9-16. CrossRef Medline

Sie KC, Rubel EW (1992) Rapid changes in protein synthesis and cell size in the cochlear nucleus following eighth nerve activity blockade or cochlea ablation. J Comp Neurol 320:501-508. CrossRef Medline

Tierney TS, Russell FA, Moore DR (1997) Susceptibility of developing cochlear nucleus neurons to deafferentiation-induced death abruptly ends just before the onset of hearing. J Comp Neurol 378:295-306. CrossRef Medline

Trune DR (1982) Influence of neonatal cochlear removal on the development of mouse cochlear nucleus: I. Number, size, and density of its neurons. J Comp Neurol 209:409-424. CrossRef Medline

Trune DR (1983) Influence of neonatal cochlear removal on the development of mouse cochlear nucleus. III. Its efferent projections to inferior colliculus. Brain Res 285:1-12. Medline

Wang Y, Hirose K, Liberman MC (2002) Dynamics of noise-induced cellular injury and repair in the mouse cochlea. J Assoc Res Otolaryngol 3:248 268. CrossRef Medline

Xiang M, Gan L, Li D, Chen ZY, Zhou L, O’Malley BW Jr, Klein W, Nathans J (1997) Essential role of POU-domain factor Brn-3c in auditory and vestibular hair cell development. Proc Natl Acad Sci U S A 94:9445-9450. CrossRef Medline

Zilberstein Y, Liberman MC, Corfas G (2012) Inner hair cells are not required for survival of spiral ganglion neurons in the adult cochlea. J Neurosci 32:405-410. CrossRef Medline 